\title{
OSLOBOĐENJE OD SUDSKIH PRISTOJBI KAO PREDUVJET OSTVARENJA PRAVA NA PRISTUP PRAVOSUĐU**
}

Sažetak: Hrvatski sustav oslobođenja od sudskih pristojbi posljednjih je godina prošao korjenite promjene. Suprotno nekadašnjem rješenju, odlučivanje je iz sudske nadležnosti premješteno u nadležnost upravnih tijela, a precizno su propisani $i$ kriteriji za oslobođenje. Uvođenje specijaliziranog upravnog tijela koje odlučuje prema unaprijed strogo propisanim pravilima obećavalo je veći broj oslobođenja, ali i veću pristupačnost sustava uopće. U izvješćima Ministarstva pravosuđa proteklih je godina zamjetan trend povećanja broja predmeta u kojima je došlo do oslobođenja od sudskih pristojbi, no te brojke same po sebi ne govore mnogo o tome funkcionira li sustav i u kojoj mjeri. Stoga se u ovom radu hrvatska zakonodavna rješenja i njihova primjena stavljaju u kontekst prakse Europskog suda za ljudska prava, a broj oslobođenja uspoređuje s brojem ovršnih postupaka pokrenutih zbog neplaćanja sudskih pristojbi. Na temelju komparativne analize $i$ empirijskih podataka iznose se zaključci o (ne)funkcioniranju sustava i predlažu njegove nužne izmjene.

Ključne riječi: $\quad$ sudske pristojbe, oslobođenje od sudskih pristojbi, pristup pravosuđu

\section{UVOD}

Pravo na pravično suđenje iz članka 6. Europske konvencije za zaštitu ljudskih prava i temeljnih sloboda (dalje: EKLJP), ${ }^{1}$ svakome jamči pravo da, radi utvrđivanja njegovih, odnosno njezinih prava i obveza građanske naravi, zakonom ustanovljeni neovisni i nepristrani sud

\footnotetext{
* Juraj Brozović, mag. iur., asistent na Katedri za građansko procesno pravo Pravnog fakulteta Sveučilišta u Zagrebu, Trg maršala Tita 14, 10000 Zagreb, Republika Hrvatska. Adresa e-pošte: juraj.brozovic@pravo.hr. ORCID: http://orcid.org/0000-0003-23624580.

** Rad je izrađen u okviru znanstvenoga projekta Hrvatski pravni sustav Pravnog fakulteta Sveučilišta u Zagrebu. Izradu ovoga rada potpomogla je i Hrvatska zaklada za znanost u okviru projekta br. 6988.

1 Narodne novine, Međunarodni ugovori, br. 18/1997, 6/1999, 14/2002, 13/2003, 9/2005, 1/2006 i 2/2010.
} 
pravično, javno i u razumnom roku ispita njegov slučaj. ${ }^{2}$ U kontekstu EKLJP-a ono prije svega podrazumijeva određena institucionalna jamstva (pravo na zakonom ustanovljeni neovisni i nepristrani sud), ali i jamstva koja se odnose na samo provođenje postupka (pravo na pravično i javno suđenje u razumnom roku). ${ }^{3}$ Za razliku od takvih izričitih jamstava, pravo na pristup pravosuđu nije izrijekom spomenuto u tekstu, no ono predstavlja nužan preduvjet za ostvarivanje drugih jamstava zajamčenim člankom 6 . EKLJP-a koja bi bez njega bila besmislena. ${ }^{4}$ To ne znači da je to pravo apsolutno i da ne može biti podložno ograničenjima. ${ }^{5}$ Međutim, takva ograničenja moraju biti proporcionalna, što podrazumijeva da imaju legitiman cilj, a odabrano sredstvo mora biti prikladno za postizanje tog cilja. ${ }^{6}$

S obzirom na to da je nekim osobama plaćanje sudske pristojbe predstavljalo znatan financijski teret, u tumačenju EKLJP-a postavilo se pitanje predstavljaju li sudske pristojbe ograničenje prava na pristup pravosuđu. Prvi predmet u kojem je ESLJP za ljudska prava (dalje: ESLJP) dobio priliku odlučivati o tom pitanju bio je predmet Kreuz protiv Poljske. ${ }^{7} \mathrm{U}$ tom je predmetu ESLJP nedvojbeno ustanovio da sudske pristojbe same po sebi ne predstavljaju ograničenje prava na pristup pravosuđu koje bi predstavljalo povredu članka 6. EKLJP-a. ${ }^{8}$ Dapače, financijska ograničenja u određenim slučajevima mogu biti prihvatljiva. ${ }^{9}$ ESLJP zapravo mora u svakom pojedinačnom slučaju procjenjivati je li iznos sudske pristojbe doveo u pitanje samu bit prava na pristup pravosuđu, uzimajući pritom u obzir kao relevantne kriterije mogućnost podnositelja da plati iznos sudskih pristojbi, kao i fazu postupka u kojoj je nametnuta obveza njihovog plaćanja. ${ }^{10}$ Sličnog je stajališta bio i Ustavni sud Republike Hrvatske (dalje: Ustavni sud RH) pri odlučivanju o ustavnosti Zakona o sudskim pristojbama (dalje: ZSP). ${ }^{11}$ Ponavljajući u osnovi istu argumentaciju kojom se koristio ESLJP, utvrdio je da "propisani sustav plaćanja sudskih pristojbi sam po sebi ne predstavlja ograničenje prava na pristup sudu", ${ }^{12}$ ali i da od takve načelne dužnosti plaćanja sudskih pristojbi "treba razlikovati točno određenu

2 Za pravo na pravično suđenje u građanskopravnim stvarima v. Uzelac, A., Pravo na pravično suđenje u građanskim predmetima: nova praksa Europskog suda za ljudska prava i njen utjecaj na hrvatsko pravo i praksu, Zbornik Pravnog fakulteta u Zagrebu, god. 60 , br. 1, 2010.

Settem, O. J., Applications of the 'Fair Hearing' Norm in ECHR Article 6(1) to Civil Proceedings With Special Emphasis on the Balance Between Procedural Safeguards and Efficiency, Springer, Cham-Heidelberg-New York-Dordrecht-London, 2016. str. 60.

4 Golder protiv Ujedinjenog Kraljevstva (4451/70 od 21. veljače 1975.), § 35. Sud je posebno istaknuo da nije riječ o “ekstenzivnom tumačenju i novoj obvezi državama članicama" (ibid., § 36).

$5 \quad$ Ibid., $\S 38$.

6 Settem, op. cit. u bilj. 4, str. 63. S obzirom na to da je ESLJP ova pravila za ograničenje prava na pristup pravosuđu prvi put spomenuo u predmetu Ashingdane protiv Velike Britanije (8225/78 od 28. svibnja 1985.), u literaturi se ta pravila nazivaju Ashingdane načelima. Susi, M., Application of the Access to Court Doctrine by the European Court of Human Rights: Estonia's Concept of Comprehensive Court Protection, German Yearbook of International Law, god. 52, $2009 .$, str. 564.

$7 \quad 28249 / 95$ od 19. lipnja 2001.

$8 \quad$ Ibid., § 60. Tako je u predmetu Iorga protiv Rumunjske ESLJP ocijenio prihvatljivim stajalište da se propisivanjem pristojbi želi suzbiti obijesno parničenje i financirati pravosuđe (4227/02 od 25. siječnja 2007., § 41.).

9 Kreuz, ibid., § 54. Pritom je ESLJP kao primjer naveo predmete Brulla Gomez de la Torre protiv Španjolske (26737/95 od 19. prosinca 1997.) u kojem je ocijenio opravdanim ograničenja pristupa vrhovnom sudu (ibid., § 33.) te Tolstoy - Miloslavsky protiv Ujedinjenog Kraljevstva (18139/91 od 13. srpnja 1995.) u kojem je ocijenio opravdanim pravila o aktorskoj kauciji (ibid., § 61.).

10 Kreuz, ibid., $§ 61$.

11 Narodne novine, br. 74/1995, 57/1996, 137/2002, 125/2011, 112/2012, 157/2013 i 110/2015 
visinu pristojbe koja u primjeni Zakona na konkretan slučaj može dovesti do ograničenja prava na pristup sudu". ${ }^{13}$

Načela utvrđena u predmetu Kreuz protiv Poljske ESLJP je dosljedno primjenjivao u velikom broju predmeta procjenjujući pritom u kojoj mjeri pojedina zakonodavna rješenja, odnosno postupanje sudova i drugih državnih tijela dovodi u pitanje samu bit prava na pristup pravosuđu. ${ }^{14}$ Iako je uloga ESLJP-a utvrditi pojedinačne povrede, a ne zamijeniti zakonodavca, ${ }^{15}$ opetovane osude država ugovornica mogu biti snažan poticaj za zakonodavne izmjene. ${ }^{16}$ ESLJP takvom je praksom i svojim autoritetom razvio opći okvir iz kojeg zakonodavci mogu iščitati određene pouke i svoja zakonodavstva u većoj mjeri približiti njegovim očekivanjima.

U kojoj mjeri zakonodavna rješenja i njihova primjena u Republici Hrvatskoj odgovaraju tim standardima? Zakon o besplatnoj pravnoj pomoći (dalje: ZBPP) ${ }^{17}$ detaljno uređuje pravila o oslobođenju od sudskih pristojbi na temelju imovinskog stanja. Tako određuje tijelo nadležno za odlučivanje o zahtjevu za oslobođenje, imovinski cenzus koji mora biti zadovoljen da bi došlo do oslobođenja, ${ }^{18}$ opseg oslobođenja, ${ }^{19}$ prava i obveze podnositelja u vezi s njegovim zahtjevom ${ }^{20}$ te druga pitanja u vezi s oslobođenjem. ${ }^{21}$ Navedene odredbe, ali i sustav u cjelini, zahtijevaju kritički osvrt. Prije svega ih je potrebno staviti u kontekst prakse ESLJP-a, a potom takvu normativnu ocjenu upotpuniti dostupnim empirijskim podacima, radi utvrđenja funkcionira li i u kojoj mjeri hrvatski sustav oslobođenja od sudskih pristojbi na zadovoljavajući način.

13 Ibid. Naravno, misli se na ocjenu Ustavnog suda RH do koje bi došlo u povodu podnesene ustavne tužbe. U sudskoj praksi Ustavnog suda RH dosad su podnesene tri takve ustavne tužbe, ali ni u jednom od tih predmeta Ustavni sud RH nije meritorno odlučivao. Naime, s obzirom na to da su bile podnesene protiv rješenja o odbijanju oslobođenja od sudskih pristojbi, što ne predstavlja pojedinačni akt tijela državne vlasti kojim je (meritorno) odlučeno o pravima i obvezama ili (...) povrijeđeno ljudsko pravo ili temeljna sloboda zajamčena Ustavom Republike Hrvatske, u smislu čl. 62. Ustavnog zakona o Ustavnom sudu RH (Narodne novine, br. 99/1999, 29/2002 i 49/2002), ustavne su tužbe bile odbačene. Vidjeti rješenje od 3. ožujka 2010., posl. br. U-III-1811/2007; rješenje od 28. listopada 2010., posl. br. U-III-2347/2010; te rješenje od 20. rujna 2012., posl. br. U-I$4144 / 2012$

Država ugovornica mora pronaći "prikladnu ravnotežu između, s jedne strane, interesa Države da prikupi sudske pristojbe za rad na predmetima te, s druge strane, interesa podnositelja da ostvari svoj zahtjev posredovanjem suda” (Kreuz, op. cit. u bilj. 8, § 66.).

Tolstoy-Miloslavsky, op. cit. u bilj. 10, §33.

16 Primjerice, u odnosu na Tursku u relativnom kratkom razmaku ESLJP je donio veći broj odluka u kojima je utvrdio povrede članka 6. EKLJP-a, s obzirom na to da turski sustav besplatne pravne pomoći nije sadržavao sve potrebne mehanizme zaštite od proizvoljnosti odluka o (ne)odobravanju besplatne pravne pomoći. Do osude je došlo u predmetima Bakan protiv Turske (50939/99 od 12. rujna 2007.), Mehmet i Suna Yigit protiv Turske (52658/99 od 17. listopada 2007.), Amaç i Okkan protiv Turske (54179/00 i 54176/00 od 20. veljače 2008.), Tunç protiv Turske (20400/03 od 7. srpnja 2008.) te Eyüp Kaya protiv Turske (17582/04 od 23. prosinca 2008.). Sud je povrede u tim predmetima utvrdio zbog tijela koje je donosilo odluku oslobođenju, manjku saslušanja stranaka u vezi sa zahtjevom te izostanka mogućnosti žalbe na odluku o odbijanju, s time da nije jasno bi li ESLJP ustanovio povredu članka 6. EKLJP i da je postojao samo jedan od navedenih razloga. Vidjeti Legal aid: procedures for grant - inability to pay court fees - arts 6(1) and 13, European Human Rights Law Review, br. 5, 2008., str. 669.-670.

Narodne novine, br. 143/2013. 


\section{USKLAĐENOST TRENUTAČNOGA UREĐENJA SA STANDARDIMA EKLJP-A}

\subsection{TIJELO NADLEŽNO ZA ODLUČIVANJE O ZAHTJEVU ZA OSLOBOĐENJE}

Dugi niz godina hrvatsko je građansko procesno pravo karakterizirao sustav sudskog oslobođenja od sudskih pristojbi, prema uzoru na pravila austrijskog građanskog postupka. ${ }^{22}$ Prvi poslijeratni Zakon o parničnom postupku iz 1957. godine ${ }^{23}$ propisivao je postupak oslobođenja, dok su osnove za oslobođenje bile propisane Osnovnim zakonom o sudskim taksama. ${ }^{24}$ Gotovo iste odredbe preuzeo je i trenutačno važeći Zakon o parničnom postupku iz 1977. godine (dalje: ZPP), ${ }^{25}$ a osnove za oslobođenja na sličan su način propisivali prvi Zakon o sudskim pristojbama (dalje: stari ZSP), ${ }^{26}$ ali i poslije doneseni i trenutačno važeći istoimeni zakon. Odredbe o oslobođenju iz temelja su reformirane donošenjem prvog Zakona o besplatnoj pravnoj pomoći (dalje: stari ZBPP). ${ }^{27} \mathrm{Uz}$ sud prvi put se kao tijelo nadležno za odlučivanje o oslobođenju od sudskih pristojbi našao ured državne uprave u županiji, ${ }^{28}$ no samo kad je riječ o oslobođenju korisnika besplatne pravne pomoći. Takvo je rješenje preuzeo i novi ZBPP. ${ }^{29}$ Kao posljedica svih tih reformi, Novelom ZPP-a iz 2013. godine brisan je niz odredbi koje su se odnosile na uvjete i način ostvarivanja prava na oslobođenje od sudskih pristojbi i od prethodnog snošenja parničnih troškova, ${ }^{30}$ a vrlo brzo nakon donošenja ZBPP-a, prestale su važiti i odredbe ZSP-a koje su se odnosile na oslobođenje od sudskih pristojbi na temelju imovinskog stanja. ${ }^{31}$ Rezultat je relativno kompleksan paralelni sustav oslobođenja u kojem odluku o oslobođenju na temelju imovinskog stanja donosi upravno tijelo, dok na temelju ostalih osnova odluku i dalje donosi sud. ${ }^{32}$

22 Danas je ovo pitanje uređeno $§ \S$ 63.-73. austrijskog Gesetz über das gerichtliche Verfahren in bürgerlichen Rechtsstreitigkeiten (Zivilprozessordnung - ZPO) (dalje: austrijski ZPO) od 1. kolovoza 1895. (RGBl. Nr. 113/1895), posljednji put izmijenjen 16. prosinca 2014. (BGBl. I Nr. 92/2014) te § 63.-73. austrijskog Gerichtsgebührengesetz (dalje: austrijski GGG) od 14. prosinca 1984. (BGBl. Nr. 501/1984) posljednji put izmijenjen 7. svibnja 2012. (BGBl. I Nr. 35/2012).

Službeni list FNRJ, br. 4/1957 i 52/1961, Službeni list SFRJ, br. 12/1965, 1/1971, 23/1972 i 6/1974.

Službeni list FNRJ, br. 16/1960, Službeni list SFRJ, br. 10/1965, 15/1965 i 8/1969 i Narodne novine, br. 52/1971 i 52/1973. Vrijedio je za područje čitave Jugoslavije, ali iznos pristojbi određivala je svaka socijalistička republika zasebno. Tako je SRH donijela Zakon o republičkim sudskim taksama (Narodne novine, br. 19/1969, 10/1971, 14/1972, 26/1973 i 19/1977).

Službeni list SFRJ, br. 4/1977, 36/1977, 36/1980, 6/1980, 69/1982, 43/1982, 58/1984, 74/1987, 57/1989, 20/1990, 27/1990, 35/1991 i Narodne novine, br. 53/1991, 91/1992, 112/1999, 129/2000, 88/2001, 117/2003, 88/2005, 2/2007, 96/2008, 84/2008, 123/2008, 57/2011, 25/2013 i 89/2014. Narodne novine, br. 20/1987, 55/1988,13/1989, 47/1989,11/1990,18/1990, 53/1991, 28/1992 i 66/1993.

27 Narodne novine, br. 62/2008.

28 Čl. 22. starog ZBPP-a. Usporedi čl. 17. ZBPP-a.

Već je i Zakonom o izmjenama i dopunama ZBPP-a (Narodne novine, br. 81/2011; dalje: ZID ZBPP/11) uveden niz odredbi koje su mnogo detaljnije od izvornog teksta starog ZBPP-a uređivale pitanje oslobođenja, s danom početka primjene od 1. siječnja 2013. godine. 
Danas o zahtjevu za oslobođenje od sudskih pristojbi na temelju imovinskog stanja, kao i o bilo kojem drugom obliku tzv. sekundarne besplatne pravne pomoći, odlučuje ured državne uprave u županiji, odnosno nadležno upravno tijelo u Gradu Zagrebu. ${ }^{33}$ Uvođenjem takvog rješenja, Republika Hrvatska svrstala se u većinski krug europskih zemalja koje odluku o odobravanju besplatne pravne pomoći prepuštaju upravnim tijelima. ${ }^{34}$ Kao tijelo nadležno za odlučivanje odabrano je ono koje omogućava najveću dostupnost građanima. ${ }^{35} \mathrm{~S}$ dvadeset i jednim uredom državne uprave u županijama te ukupno devedeset ispostava, čini se da je u kontekstu tijela državne uprave doista odabrano ono koje je građanima najdostupnije. Međutim, upitno je u kojoj je mjeri ugrožena nepristranost u odlučivanju koja je, barem na razini oborive predmnjeve, postojala u vrijeme dok je o zahtjevu odlučivao sud. Naime, nepristranost se pokazala važnim kriterijem pri ocjenjivanju je li došlo do povrede članka 6. EKLJP-a u kontekstu oslobođenja od sudskih pristojbi.

U predmetu Iorga protiv Rumunjske, ${ }^{36}$ podnositelji su protiv Ministarstva financija podnijeli tužbu za povrat imovine oduzete za vrijeme komunističke vladavine. U žalbenom postupku naloženo im je plaćanje sudske pristojbe koja je iznosom bila gotovo jednaka visini njihove mirovine kao jedinog prihoda. S obzirom na to da pristojbe nisu plaćene, prvostupanjski je sud odbacio žalbu, na što su se podnositelji ponovno žalili. U međuvremenu su Ministarstvu financija podnijeli zahtjev za oslobođenje od sudskih pristojbi, no on je odbijen kao neutemeljen pa je drugostupanjski sud potvrdio odluku o odbačaju. ${ }^{37}$ Iako je primijetio da je iznos pristojbe pokrivao gotovo čitav iznos mirovine podnositelja, ESLJP je povredu članka 6. EKLJP-a utvrdio zbog toga što je o oslobođenju od sudskih pristojbi odlučivalo Ministarstvo financija koje je ujedno bilo i stranka u postupku, što je dovelo u pitanje njegovu nepristranost. Nadalje, nije bilo ni prikladne mogućnosti sudskog ispitivanja njegove odluke. ${ }^{38}$

Preslikano na hrvatsku situaciju, uočavaju se neke razlike. Prije svega, na rješenje o odbijanju besplatne pravne pomoći moguće je u roku od petnaest dana podnijeti žalbu Ministarstvu pravosuđa (dalje: Ministarstvo), a protiv odluke Ministarstva pokrenuti upravni spor. ${ }^{39}$ Također, neplaćanje sudske pristojbe ne dovodi do odbacivanja tužbe, nego je jedina posljedica prisilno izvršenje na temelju rješenja o pristojbama. ${ }^{40}$ Međutim, iako uredi državne uprave $\mathrm{u} z ̌ u p a n i j i$ formalno ne mogu biti stranke u parničnom postupku s obzirom na to da nemaju pravnu osobnost, ${ }^{41}$ oni bi mogli biti strankom u upravnom sporu u vezi s nekim od poslova koji spadaju u njegov djelokrug. Prije svega, to bi mogao biti slučaj u vezi s neposrednim

Uizjéću Europske komisije za ucinkn odluku donose i sudska i upravna tijela. European judicial systems: Efficiency and quality of justice. CEPEJ Studies, No. 23, Edition 2016 (2014 data), str. 69. Izvješće dostupno na: http://www.coe.int/t/dghl /cooperation/cepej/evaluation/2016/ publication/CEPEJ\%20Study\%2023\%20report\%20EN\%20web.pdf (21. ožujka 2017.).

Konačni prijedlog ZBPP-a, 2008., str. 38.

Op. cit. u bilj. 9.

Ibid., §§ 7.-21.

Ibid., $§ 47$.

Čl. 17. st. 4.-7. ZBPP-a.

Vidjeti infra 2.5. Pravne posljedice neplaćanja sudskih pristojbi.

Čl. 77. ZPP-a. To bi mogla biti isključivo Republika Hrvatska. 
provođenjem zakona i drugih propisa te, a fortiori, rješavanja u upravnim stvarima u prvom stupnju. ${ }^{42}$ Stoga nije nezamisliva situacija u kojoj o oslobođenju od sudskih pristojbi odlučuje isto tijelo koje je protustranka u upravnom sporu. Upitno je, međutim, može li eventualna pristranost dovesti do nepovoljnog rezultata za stranke i ograničiti ili čak onemogućiti njezin pristup pravosuđu. To se ipak čini malo vjerojatnim. Prije svega, ured državne uprave odlučuje na temelju strogih zakonom unaprijed propisanih kriterija koji su vezani uz podatke iz javnih evidencija. ${ }^{43} \mathrm{U}$ konačnici, eventualna proizvoljnost može se s uspjehom napadati žalbom, a prema potrebi i sudski preispitivati. Stoga smatramo da su načela iz predmeta Iorga u Republici Hrvatskoj dosljedno primijenjena te da nema straha od proizvoljnosti odluka ureda državne uprave u županiji zbog sukoba interesa. ${ }^{44}$

\subsection{OVLAŠTENICI PRAVA NA OSLOBOĐENJE OD SUDSKIH PRISTOJBI}

Ovlaštenici općeg oslobođenja od sudskih pristojbi na temelju odredaba ZSP-a mogu biti i fizičke i pravne osobe. ${ }^{45} \mathrm{~S}$ druge stane, kao korisnik besplatne pravne pomoći definirana je isključivo fizička osoba koja koristi vrstu pravne pomoći propisanu ZBPP-om. ${ }^{46}$ Time zakonodavac nije odstupio od dosadašnjeg rješenja predviđenog bivšim člankom 172. ZPP-a prema kojem, doduše, nisu izričito bile isključene pravne osobe, ali je takvo tumačenje iznjedrila sudska praksa. ${ }^{47} \mathrm{U}$ svakom slučaju, zakonodavac je novom definicijom korisnika besplatne pravne pomoći iz opsega oslobođenja od sudskih pristojbi na temelju imovinskog stanja isključio širok krug pravnih osoba te se one, neovisno o svojem imovinskom stanju, ne mogu naći u ulozi ovlaštenika prava na oslobođenje od sudskih pristojbi. I takva je praksa država ugovornica bila predmet kontrole ESLJP-a.

U predmetu VP Diffusion Sarl protiv Francuske, ${ }^{48}$ postavilo se pitanje je li odbijanjem oslobođenja od sudskih pristojbi podnositeljevom trgovačkom društvu povrijeđeno pravo na pristup pravosuđu. Podnositeljevo je društvo podnijelo tužbu za naknadu štete zbog iznenadnog raskida ugovora i prekida poslovne suradnje. S obzirom na to da je tužbeni zahtjev odbijen,

42 Čl. 54. Zakona o sustavu državne uprave (Narodne novine, br. 150/2011, 12/2013, 93/2016 i 104/2016). Uredi državne uprave o županijama odlučuju i o naknadi za oduzetu imovinu sukladno Zakonu o naknadi za imovinu oduzetu za vrijeme jugoslavenske komunističke vladavine (Narodne novine, br. 92/1996, 39/1999, 42/1999, 92/1999, 43/2000, 131/2000, 27/2001, 34/2001, $65 / 2001,118 / 2001,80 / 2002$ i 81/2002), stoga je njihov položaj usporediv s položajem Ministarstva financija u predmetu Iorga.

Čl. 13.-15. ZBPP-a.

Međutim, to ne znači da uredi državne uprave u županiji imaju sve kvalitete potrebne za donošenje te odluke i da stavljanje odluke u njihov djelokrug predstavlja najsvrsishodnije rješenje. $S$ obzirom na to da je to pitanje usko vezano uz kriterije za odobravanje sekundarne pravne pomoći i fleksibilnost u njihovoj primjeni, o tome će više biti riječi infra pod 2.3. Kriteriji za oslobođenje od sudskih pristojbi na temelju imovinskog stanja.

Prema čl. 16. st. 1. ZSP-a, kao ovlaštenici oslobođenja mogu se pojaviti sljedeće pravne osobe: Republika Hrvatska (t. 1.), humanitarne organizacije i organizacije koje se bave zaštitom invalida i obitelji poginulih, nestalih i zatočenih u obavljanju humanitarne djelatnosti (t. 10.), tužitelji u postupcima za zaštitu ustavom zajamčenih ljudskih prava i sloboda protiv konačnih pojedinačnih akata (t. 17.), tužitelji u sporovima o naknadi štete zbog onečišćenja okoliša (t. 18.), sindikati i udruge sindikata više razine (t. 19.) te strana država pod uvjetom uzajamnosti (čl. 16. st. 2. ZBPP-a).

6 Čl. 4. st. 1.t. 1. ZBPP-a.

Odluka Visokog trgovačkog suda Republike Hrvatske od 3. prosinca 1996., posl. br. Pž- 2959/96, cit. u Čizmić, J., O pružanju besplatne pravne pomoći, Zbornik Pravnog fakulteta Sveučilišta u Rijeci, god. 31, br. 1, 2010., str. 419.

8 14565/04 od 5. travnja 2004. 
društvu je naloženo plaćanje sudskih troškova. Podnositeljevo društvo se s predmetom htjelo obratiti i Kasacijskom sudu, ali je zbog lošeg imovinskog stanja i prijetnje stečaja, zatražilo besplatnu pravnu pomoć. Ona je odbijena pod obrazloženjem da trgovačka društva troškove postupka mogu odbiti kao porezno priznati rashod. ${ }^{49}$ Ocjenjujući takvo postupanje, ESLJP je izrazio stajalište da se razlikovanje u pravu na besplatnu pravnu pomoć između pravnih osoba koje obavljaju i ne obavljaju gospodarsku djelatnost ne može smatrati proizvoljnim jer je objektivno opravdano poreznim propisima. ${ }^{50}$

Slično je odlučeno i u predmetu C.M.V.M.C. O Limo protiv Španjolske, ${ }^{51}$ u kojem je ESLJP implicitno podržao zakonodavno rješenje španjolskog zakonodavca prema kojem pravo na besplatnu pravnu pomoć imaju samo neprofitne pravne osobe. Negirajući povredu članka 6. EKLJP-a, još je jednom istaknuo da priznavanje prava samo nekim pravnim osobama ne predstavlja samo po sebi ograničenje prava na pristup pravosuđu.

U nizu predmeta, doduše, nije bilo dvojbe može li trgovačko društvo zahtijevati oslobođenje jer je ono bilo predviđeno domaćim pravom, ali je ESLJP utvrdio povrede. Predmet TeltronicCATV protiv Poljske ${ }^{52}$ jedan je od prvih predmeta u kojem je ustanovljena povreda prava na pristup pravosuđu pravnoj osobi koja nije oslobođena od sudskih pristojbi. Naime, iako je trgovačko društvo tražilo oslobođenje zbog nedostatnih sredstava i činjenice da bi njihovo plaćanje društvo dovelo do stečaja, prvostupanjski i drugostupanjski sud odbili su taj zahtjev. Obrazložili su to informacijama o prihodima i činjenicom da je društvo moglo u određenoj fazi poslovanja sačuvati dovoljno financijskih sredstava za plaćanje sudskih pristojbi. ${ }^{53}$ Takav je stav ESLJP smatrao neprihvatljivim i samo hipotetički mogućim. Primijetio je i da nisu uzete u obzir i obveze društva, kao ni navod podnositelja da bi plaćanje pristojbi dovelo do insolventnosti i stečaja. ${ }^{54}$

Sličan je bio ishod i predmeta FC Mretebi protiv Gruzije. ${ }^{55}$ Nogometni klub tražio je oslobođenje od sudskih pristojbi i u prvostupanjskom i u drugostupanjskom postupku, pozivajući se na financijske teškoće te kasniju insolventnost. Predložio je i djelomično oslobođenje, odnosno obročno plaćanje, no svi su prijedlozi odbijeni, što je rezultiralo odbačajem žalbe. ${ }^{56}$ I u ovom je predmetu ESLJP domaćem sudu zamjerio uzimanje u obzir isključivo prihoda bez rashoda, a nije pokazao namjeru provjeravati navode o insolventnosti. Nije uzeo u obzir ni prijedlog za djelomično oslobođenje ni prijedlog za obročno plaćanje te je zbog toga postupanje nacionalnog suda ESLJP ocijenio arbitrarnim. ${ }^{57}$

\footnotetext{
49 Ibid., § 2.-12.

$50 \quad$ Ibid., $§ 18$.

$5133732 / 05$ od 24. studenog 2009, § 26.

$52 \quad 48140 / 99$ od 10. siječnja 2006.

53 Ibid., §§ 10.-19.

54 Ibid., §§ 55.-56. Međutim, u izdvojenom mišljenju suci Baka, Garlicki i Popović nisu smatrali prihvatljivim preispitivanje od strane ESLJP-a onih činjenica koje je u boljoj poziciji ispitivati domaći sud, a posebno su iznijeli svoj stav o očekivanom ponašanju trgovačkih društava: "Svako trgovačko društvo mora uzeti u obzir svoj poslovni rizik, posebno ako, kao u ovom slučaju, sve svoje resurse ulaže u jednu veliku transakciju. Sudski postupci (i sudske pristojbe) predstavljaju očitu komponentu poslovnog rizika i nije uloga Suda u Strasbourgu da nadoknadi gubitke trgovačkog društva kad ono nije unaprijed uzelo u obzir taj rizik" (prijevod autora). 
Iz navedenih presuda ESLJP-a ne može se zaključiti da postoji dužnost države ugovornice omogućiti pravnim osobama oslobođenje od sudskih pristojbi. ${ }^{58} \mathrm{~S}$ druge strane, ako se država nalazi među onim državama ugovornicama koje predviđaju oslobođenje za pravne osobe, dužne su slijediti pravila uspostavljena od strane ESLJP-a: ako na to nisu ovlaštene sve pravne osobe, takvo razlikovanje mora biti objektivno opravdano (npr. poreznim propisima), a ocjena prihoda onih pravnih osoba koje su na to ovlaštene, nikako ne smije biti arbitrarna.

U osnovi se slažemo sa stavom Europske komisije iz Prijedloga Direktive Vijeća 2003/8/ EZ od 27. siječnja 2003. o unapređenju pristupa pravosuđu u prekograničnim sporovima utvrđivanjem minimalnih zajedničkih pravila o pravnoj pomoći u takvim sporovima (dalje: Direktiva $)^{59}$ da i neke pravne osobe "mogu trebati pravnu pomoć iz istih razloga kao i fizičke osobe, tj. kad nemaju dostatna sredstva za snošenje troškova postupka”. ${ }^{60}$ Dakako, to ne znači da bi besplatnu pravnu pomoć nužno trebalo omogućiti svim pravnim osobama. Upitno je bi li, u slučaju da hrvatsko pravo poznaje ovlaštenje pravnih osoba na oslobođenje od sudskih pristojbi na temelju imovinskog stanja, bilo opravdano iz kruga ovlaštenika isključiti trgovačka društva. S time u vezi, valja istaknuti da hrvatsko pravo ne poznaje porezne olakšice poput onih u francuskom pravu iako trošak ovršnog postupka nije u potpunosti pravno irelevantan u kontekstu poreza na dobit. ${ }^{61}$ No takve olakšice bez daljnjega ne postoje u slučaju neprofitnih pravnih osoba. Odgovor na pitanje postaje još složeniji stavljanjem u kontekst primjene propisa Europske unije.

Naime, pri donošenju Direktive raspravljano je imaju li i pravne osobe pravo na besplatnu pravnu pomoć. Uvažavajući razlike između država članica, Europska komisija u izvorni je prijedlog teksta Direktive predvidjela pravnu pomoć samo za neprofitne pravne osobe, ali je prijedlog da pravne osobe uđu u tekst na kraju u potpunosti otpao. ${ }^{62}$ Međutim, novo svjetlo na ovo pitanje bacila je presuda ESLJP-a pravde u predmetu DEB Deutsche Energiehandels - und Beratungsgesellschaft mbH protiv Njemačke. ${ }^{63} \mathrm{U}$ tom je predmetu njemački sud postavio prethodno pitanje derogira li, u postupcima za naknadu štete protiv država članica zbog propusta implementacije direktiva, pravo na učinkovito pravno sredstvo i pravično suđenje iz članka 47. Povelje o temeljnim pravima (dalje: Povelja ${ }^{64}$ pravilo domaćeg prava o prethodnom snošenju troškova i pravilo prema kojem pravna osoba ne može ostvariti pravo na pravnu pomoć iako nije u mogućnosti snositi te troškove. Svjestan izostanka općeg pravila i ujednačene prakse među državama članicama, kao i činjenice da velik broj država članica, poput Francuske, ra-

58 Upravo na tom tragu, francuska je vlada u predmetu VP Diffusion Sarl istaknula da velik broj država ugovornica ne poznaje oslobođenje od sudskih pristojbi za pravne osobe. VP Diffusion Sarl, op. cit. u bilj. 49, § 27.

59 Službeni glasnik L 26, 31. ožujka 2003., str. 41.-47. (posebno izdanje na hrvatskom jeziku: Poglavlje 19, Volumen 3, str. 105.111.), celex 32003L0008.

60 Pojašnjenje čl. 15. Prijedloga Direktive. V. COM(2002) 13 final - 2002/0020 (CNS), celex 52002AE0687.

61 Pristojba sama po sebi nema poreznopravni značaj, no za ovršenika trošak prisilne naplate predstavlja porezno priznati rashod, osim kad je riječ o prisilnoj naplati poreza ili drugih davanja. Arg. a contrario ex čl. 7. st. 1. t. 7. Zakona o porezu na dobit (Narodne novine, br. 177/2004, 90/2005, 57/2006, 146/2008, 80/2010, 22/2012, 148/2013, 143/2014, 50/2016 i 115/2016). Cutvarić, M., Naknada troškova parničnog i ovršnog postupka i obračun PDV-a, Računovodstvo i financije, br. 12/2014, str. 119. konačni tekst Direktive nakon provođenja zakonodavnog postupka pred Vijećem ministara nije ušao takav prijedlog Europske komisije.

63 Predmet C-279/09, 22. prosinca 2010. 
zlikuje profitne od neprofitnih pravnih osoba, nezavisni odvjetnik Mengozzi smatrao je da, $u$ duhu načela iskrene suradnje, članak 47. Povelje ne bi trebalo tumačiti tako široko da pravo na besplatnu pravnu pomoć nužno obuhvaća i pravne osobe. ${ }^{65} \mathrm{Na}$ tom tragu, ESLJP pravde je, odgovarajući na prethodno pitanje njemačkom sudu, istaknuo da se pravne osobe mogu pozivati na članak 47. Povelje, ali da je na nacionalnom sudu da odredi predstavljaju li uvjeti za odobravanje besplatne pravne pomoći razmjerno ograničenje prava na pristup pravosuđu. Kao potencijalne kriterije za ocjenu naveo je predmet spora i njegova važnost, vjerojatnost uspjeha u sporu, kompleksnost postupka i primjenjivog prava, visinu financijske obveze, kao i mogućnost podnositelja da se učinkovito predstavlja pred sudom. U odnosu na pravne osobe, posebno je istaknuo da se pritom može voditi računa o tome je li riječ o profitnoj ili neprofitnoj organizaciji, kakve su financijske mogućnosti dioničara/članova društva te kakva je njihova stvarna mogućnost da prikupe nužna sredstva. ${ }^{66}$ Ovakvo stajalište ESLJP-a pravde u dijelu literature shvaćeno je kao svojevrsna obveza da se pravne osobe u većoj mjeri uzmu kao potencijalni ovlaštenici prava na oslobođenje od sudskih pristojbi. ${ }^{67}$ Naknadno je i potvrđeno u predmetu GREP GmbH protiv Slobodne Države Bavarske ${ }^{68}$ u kojem, u kontekstu primjene Uredbe Vijeća (EZ) br. 44/2001 od 22. prosinca 2000. o nadležnosti, priznavanju i izvršenju sudskih odluka u građanskim i trgovačkim stvarima, ${ }^{69}$ pravnoj osobi nije omogućena besplatna pravna pomoć jer je zatražena u okviru ovršnog postupka. ${ }^{70}$

Iako je Republika Hrvatska najmlađa država članica Europske unije, koja je u postupku pristupanja morala svoje zakonodavstvo u potpunosti uskladiti s pravnom stečevinom, otada je donesen velik broj direktiva, a Republika Hrvatska nije ih sve u predviđenom roku i implementirala. ${ }^{71} \mathrm{U}$ trenutku kad izostane implementacija neke od direktiva koje izravno utječu na poslovanje u gospodarstvu, vjerojatnost vođenja postupka protiv Republike Hrvatske zbog propusta pravodobne implementacije više neće biti samo teoretska nego stvarna i izvjesna. Stoga će načela utvrđena u predmetu $D E B$ biti relevantna u kontekstu prekograničnih parničnih postupaka, a onemogućavanje pravnim osobama da ostvare pravo na besplatnu pravnu pomoć, uključujući pravo na oslobođenje od sudskih pristojbi na temelju imovinskog

65 Mišljenje nezavisnog odvjetnika Mengozzija od 2. rujna 2010., §§ 98.-100.

66 Predmet DEB, op. cit. u bilj. 64, §§ 59.-62.

67 Zaccarono, G., Consequences of Accession of the EU to the ECHR on the Jurisdictional Architecture of Europe [article] Law of Ukraine: Legal Journal, god. 2013, br. 3, 2013., str. 287. V. i Slonina, M., Verfahrenshilfe für juristische Personen: Ein Weihnachtsgeschenk des EuGH?, ecolex, br. 5/2011, citirano u Roth, M., Litigating in Ausrtia - Are Costs and Fees Worth it?, u: Reimann, M. (ur.), Cost and Fee Allocation in Civil Procedure: A Comparative Study, Springer, Dordrecht-Heidelberg-LondonNew York, 2012., str. 76. Slonina se, tumačeći presudu u predmetu DEB, kritički osvrnuo na izmjene austrijskog ZPO-a iz 2009. koje su iz kruga ovlaštenih pravnih osoba isključile profitne pravne osobe.

68 Predmet C-156/12, 13. lipnja 2012.

69 Službeni glasnik L 12, 16. siječnja 2001., str. 1,-23,, celex 32001R0044.

70 O odnosu ovih presuda s presudama Europskog suda pravde, v. Palmer, E. et al. (ur.), Access to Justice Beyond the Policies and Politics of Austerity, Hart Publishing, Oxford and Portland, Oregon, 2016., str. 58.-60.

71 Primjerice, na vrijeme nisu implementirane: Direktiva 2014/23/EU Europskog parlamenta i Vijeća od 26. veljače 2014. o dodjeli ugovorâ o koncesiji (Službeni glasnik L 94, 28. ožujka 2014., str. 1.-64., celex 32014L0023), Direktiva 2014/24/EU Europskog parlamenta i Vijeća od 26. veljače 2014. o javnoj nabavi i o stavljanju izvan snage Direktive 2004/18/EZ (Službeni glasnik L 94, 28. ožujka 2014., str. 65.-242., celex 3A32014L0024) te Direktiva 2014/25/EU Europskog parlamenta i Vijeća od 26. veljače 2014. o nabavi subjekata koji djeluju u sektoru vodnog gospodarstva, energetskom i prometnom sektoru te sektoru poštanskih usluga i stavljanju izvan snage Direktive 2004/17/EZ (Službeni glasnik L 94, 28. ožujka 2014., str. 243.-374., celex 32014L0025). M. R., Prijete sankcije: Hrvatska kasni s implementacijom europskih direktiva o javnoj nabavi i koncesijama, Portal index.hr: 24. svibnja 2016., www.index.hr/vijesti/clanak/prijete-sankcije-hrvatska-kasni-s-implementacijom-europskih-direktiva-o-javnojnabavi-i-koncesijama/895218.aspx (24. ožujka 2017.). 
stanja, moglo bi se smatrati povredom europskog prava ako ne bude dostatno obrazloženo i stavljeno u kontekst legitimnog cilja. Stoga u svjetlu odluke u predmetu $D E B$ smatramo da bi ZBPP trebao barem za neprofitne pravne osobe (domaće i inozemne) predvidjeti mogućnost ostvarenja prava na besplatnu pravnu pomoć.

\subsection{KRITERIJI ZA OSLOBOĐENJE OD SUDSKIH PRISTOJBI NA TEMELJU IMOVINSKOG STANJA}

\subsubsection{Geneza pravila o pretpostavkama za oslobođenje}

Prije 2013. godine, oslobođenje od sudskih pristojbi na temelju imovinskog stanja djelomično je bilo uređeno odredbama ZSP-a, a djelomično ZPP-a. U oba slučaja, temeljni uvjet za oslobođenje bio je da stranka "prema svojem općem imovnom stanju ne može podmiriti sudsku pristojbu bez štete za nužno uzdržavanje sebe i svoje obitelji”. ${ }^{72}$ To je bila opća formula koja je sudu omogućavala da uzme u obzir sve osobitosti svakog pojedinačnog slučaja, kao što su pridoda spora i njegova vrijednost, imovno stanje stranke i njezinih članova obitelji, broj članova obitelji kojeg je stranka dužna uzdržavati i slično. ${ }^{73}$ Imovno stanje utvrđivalo se na temelju potvrde o imovnom stanju koju izdaje Porezna uprava Ministarstva financija, a koju je stranka bila dužna podnijeti uz prijedlog za oslobođenje. ${ }^{74}$ Paralelno s ovim sustavom, starim ZBPP-om uvedeni su strogi zakonski kriteriji za ostvarivanje prava na besplatnu pravnu pomoć. Prvi put izričito je propisan imovinski cenzus, a uzimali su se obzir ukupni primici i dohodak podnositelja i njegovih članova kućanstva, imovina u novčanom i nenovčanom obliku te nekretnine. ${ }^{75}$ Međutim, manjak fleksibilnosti doveo je do toga da Ustavni sud RH ukine navedenu odredbu, ocijenivši da tako uređen imovinski cenzus "onemogućuje ostvarenje prava na besplatnu pravnu pomoć širokom krugu ugroženih osoba” ${ }^{76}$ Zakonske izmjene nakon te odluke donekle su ublažile nefleksibilnost omogućivši odobravanje besplatne pravne pomoći i osobama koje ne ispunjavaju te uvjete ako je njihovo imovno stanje takvo da bi s obzirom na stvarne ili predvidive troškove postupka, plaćanje troškova postupka ugrozilo uzdržavanje podnositelja zahtjeva i članova kućanstva. ${ }^{77}$ Time je zapravo ponovljena formulacija koja se

72 Bivši čl. 15. st. 1. ZSP-a i bivši čl. 172. st. 1. ZPP-a.

73 Bivši čl. 15. st. 3. ZSP-a. V. i Triva, S.; Dika, M., Građansko parnično procesno pravo, Sedmo izmijenjeno i dopunjeno izdanje, Narodne novine, Zagreb, 2004., str. 474.

Bivši čl. 15. st. 2. u vezi s čl. 14. ZSP-a.

75 Bivši čl. 8. st. 1. starog ZBPP-a.

76 Odluka i Rješenje Ustavnog suda RH od 6. travnja 2011., posl. br. U-I-722/2009, § 7.5. Iako je Ministarstvo izdalo uputu uredima državne uprave od 22. travnja 2010. (Klasa: 007-01/09-01/223, Ur. broj: 514-05-03-02/1-10-51) prema kojoj je omogućena određena doza fleksibilnosti, Ustavni sud RH takvu je uputu smatrao protivnom načelu određenosti te izrazio zabrinutost da bi takva uputa mogla dovesti do proizvoljnosti i neujednačenosti te tako ugroziti vladavinu prava kao jednu od najviših ustavnih vrednota (ibid., $§ \S 7.4 .-7.5$.). S obzirom na to da je stari ZBPP donesen bez ocjene stvarnih potreba potencijalnih korisnika, ovakav ishod ne iznenađuje. Johnsen, J.; Stawa, G.; Uzelac, A., Ocjena hrvatskog Zakona o besplatnoj pravnoj pomoći i njegove provedbe u praksi, Centar za ljudska prava, Zagreb, 2011., str. 11. Dostupno na http://www.alanuzelac.from.hr/pubs/E15Evaluation-CLAA2010hrv.pdf (26. travnja 2017.).

77 Čl. 8. st. 2. starog ZBPP-a. Međutim, ni ove promjene nisu dovele do željenih rezultata i nisu u potpunosti riješile sve probleme koje je spomenuo Ustavni sud RH. Uzelac, A.; Preložnjak, B., The Development of Legal Aid Systems in the Western Balkans. A Study of Controversial Reforms in Croatia and Serbia, Kritisk Iuss, Utgitt av Rettspolitisk Forening (Liber amicorum - Jon T. Johnsen), god. 38, br. 3-4, 2012., str. 267. Usp. 4. Jelinić, Z.; Knol Radoja, K., Analiza hrvatskoga sustava besplatne pravne 
već nalazila u ZSP-u i ZPP-u. No, tim je zakonskim izmjenama znatno proširena i mogućnost suda da odobri tzv. pravnu pomoć zbog razloga pravičnosti. Naime, osobe čiji je zahtjev nadležni ured državne uprave odbio dobile su mogućnost podnijeti zahtjev sudu za odobravanje pravne pomoći. ${ }^{78}$ Sud je radi utvrđivanja imovnog stanja polazio od stanja utvrđenog od strane nadležnog ureda, a bio je ovlašten i sam, po službenoj dužnosti, pribavljati potrebne podatke i obavijesti od ureda, drugih institucija, predlagatelja ili na drugi prikladan način. ${ }^{79}$ Pri odlučivanju o prijedlogu sud je trebao voditi računa o nekoliko kriterija, od kojih su se samo kriterij imovinskog stanja i kriterij složenosti postupka preklapali s općim kriterijima za odobravanje besplatne pravne pomoći. Kao dodatne kriterije, sud je mogao uzeti u obzir i potrebu stručne pravne pomoći predlagatelju, imajući na umu potrebu postizanja ravnopravnosti stranaka u postupku te druge mogućnosti osiguravanja stručne pravne pomoći, sposobnost predlagatelja da se sam zastupa, postojanje potrebe i obveze predlagatelja da položi predujam za troškove postupka radi nastavka postupka, ali i sve druge okolnosti koje mogu biti od utjecaja na odluku. ${ }^{80}$ Pravila o pravnoj pomoći zbog razloga pravičnosti bila su zamišljena kao "korektiv za sve slučajeve kada prema općim odredbama Zakona korisnik ne bi ostvario uvjete za pravnu pomoć." ${ }^{1}$ S obzirom na to da su ta pravila stupila na snagu 1. siječnja 2013., dakle samo godinu dana prije stupanja na snagu novog ZBPP-a, nije bilo prave prilike da te odredbe zažive u praksi. ${ }^{82}$

Trenutačno važeći ZBPP ova je pravila iz temelja izmijenio. Više ne postoje odredbe o pravnoj pomoći zbog razloga pravičnosti pa odluku o oslobođenju na temelju imovinskog stanja sada može donijeti samo ured državne uprave, neovisno o kakvom postupku je riječ, no samo ako su materijalne prilike podnositelja zahtjeva takve da bi plaćanje sudskih pristojbi moglo ugroziti uzdržavanje podnositelja zahtjeva i članova kućanstva, uz uzimanje u obzir visine sudskih pristojbi u postupku u kojem se traži oslobođenje. ${ }^{83}$ Kao i u starom ZBPP-u precizno je propisan imovinski cenzus koji mora biti zadovoljen da bi osoba ostvarila pravo na besplatnu pravnu pomoć, a precizno su propisane i iznimke od općeg pravila. Stranka ima pravo na sekundarnu pravnu pomoć, što uključuje i pravo na oslobođenje od sudskih pristojbi, ako njezin ukupan prihod i ukupan prihod članova njezina kućanstva mjesečno po članu kućanstva ne prelazi iznos proračunske osnovice, a vrijednost njihove cjelokupne imovina ne prelazi iznos

pomoći u građanskim stvarima u svjetlu dosadašnje prakse Europskoga suda za ljudska prava, Pravni vjesnik, god. 30, br. 2, 2014.

78 Čl. 42. st. 1. starog ZBPP-a. Postojala je mogućnost da sud o tome odlučuje i prije nadležnog ureda kada je to potrebno radi hitnosti postupka ili sprečavanja odugovlačenja postupka. Međutim, to je bilo moguće samo kad je bila riječ o zahtjevu za oslobođenje od plaćanja troškova sudskog postupka (ne i za druge oblike besplatne pravne pomoći). Arg. ex čl. 42. st. 2. starog ZBPP-a.

C̆l. 43. st. 1. starog ZBPP-a.

$80 \quad$ Čl. 43. st. 2. starog ZBPP-a.

81 Konačni prijedlog Zakona o izmjenama i dopunama ZBPP-a, 2011., str. 34.

82 ZID ZBPP/11 unio je veliku pomutnju među stranke koje su tražile oslobođenje od sudskih pristojbi jer je sud samo iznimno postao tijelo nadležno za odlučivanje o oslobođenju od sudskih pristojbi na temelju imovinskog stanja. Rezultat je bio odbačaj zbog apsolutne nenadležnosti i eventualno nedokazivanje posebnih pretpostavki iz čl. 43. starog ZBPP-a. V. primjerice rješenja Županijskog suda u Varaždinu od 22. rujna 2014., posl. br. Gž-4590/14; od 1. travnja 2015., posl. br. Gž-4733/14; te od 25. rujna 2015., posl. br. Gž-2254/14, ali i rješenje Županijskog suda u Zagrebu od 28. siječnja 2014., posl. br. Gž-7559/13. 
od šezdeset proračunskih osnovica. ${ }^{84}$ Međutim, ako osoba zbog objektivnih razloga ne može raspolagati ukupnim prihodima i imovinom, ne uzima se u obzir čitav prihod i sva imovina, nego samo onaj dio prihoda i imovine koji je raspoloživ. ${ }^{85}$ Opće je pravilo dodatno ublaženo pravilima o prihodima i imovini koji se ne uzimaju u obzir pri procjeni imovinskog stanja, ${ }^{86} \mathrm{a}$ posebno su propisane i situacije u kojima se imovinsko stanje uopće ne utvrđuje. ${ }^{87}$ Usporedi li se ovakvo uređenje s onim prethodnim, osjetna je fleksibilizacija sustava iako je upitno može li ured državne uprave kao upravno tijelo na adekvatan način ocjenjivati sve činjenice relevantne za donošenje odluke o oslobođenju. Upravo prilagodljivost svakom pojedinom slučaju važna je u kontekstu prava na pristup pravosuđu jer EKLJP jamči prava koja su stvarna i učinkovita, a ne samo teoretska. ${ }^{88}$

\subsubsection{Stav ESLJP-a o kriterijima za oslobođenje}

ESLJP je u predmetu Kreuz postavio opća pravila za ocjenu prihvatljivosti sudskih pristojbi u konkretnom sudskom postupku. Primjenjujući ta načela, povredu članka 6. EKLJP-a utvrdio je i u tom predmetu. Naime, podnositelj je podnio tužbu za naknadu štete protiv lokalne uprave zbog povreda vezanih uz izdavanje lokacijske dozvole koje je pravomoćno utvrdio i Visoki upravni sud. Podnositelj je ujedno podnio zahtjev za oslobođenje od sudske pristojbe uz kojeg je priložio i izjavu o prihodima i imovini iz koje je bilo razvidno da ne može podmiriti trošak pristojbe. Prvostupanjski sud je odredio plaćanje sudske pristojbe u iznosu prosječne godišnje plaće u Poljskoj, smatrajući da je podnositelj kao poduzetnik trebao uzeti u obzir mogućnost vođenja sudskih postupaka. S obzirom na to da je i žalbeni sud smatrao da podnositelj ničime nije dokazao nemogućnosti plaćanja iznosa sudskih pristojbi, po podnositeljevoj tužbi nikad nije postupano. ${ }^{89}$ Osim što je primijetio da je riječ o značajnom iznosu kad se uzme u obzir prosječna godišnja plaća, ESLJP je kritizirao zaključke nacionalnog suda da samo uključivanje

84 Čl. 14. st. 1. ZBPP-a. Prema Zakonu o izvršavanju Državnog proračuna Republike Hrvatske za 2017. godinu (Narodne novine, br. 119/2016), proračunska osnovica iznosi 3.326,00 kuna. Relevantno razdoblje za procjenu prihoda i vrijednosti imovine je dvanaest mjeseci prije početka mjeseca u kojem se zahtjev podnosi (čl. 14. st. 4. ZBPP-a).

85 Čl. 14. st. 2. ZBPP-a. Objektivnim razlozima smatraju se osobito: postojanje izvanrednih troškova liječenja podnositelja zahtjeva ili članova kućanstva koji nisu obuhvaćeni zdravstvenim osiguranjem, troškovi ortopedskih pomagala, rehabilitacije i drugih usluga koje osobama s invaliditetom nisu osigurani zdravstvenim osiguranjem, troškovi obrazovanja za djecu $s$ teškoćama u razvoju, ostali troškovi nastali kao posljedica više sile (požar, potres, poplava i slično) i vlasništvo imovine koja se ne može unovčiti ili je njezino unovčenje teško provedivo.

86 Čl. 15. st. 2. ZBPP-a. Tako se ne uzimaju u obzir ukupni prihodi i imovina počinitelja nasilja u obitelji ako je podnositelj žrtva toga nasilja; ukupni prihodi i imovina članova kućanstva koji sudjeluju u postupku kao protivnici podnositelja ili je njihov interes u suprotnosti s njegovim interesom; dio nekretnine u kojoj živi podnositelj, nužan za ostvarenje osnovnih životnih potreba podnositelja i članova kućanstva; vrijednost dijela nekretnine koja služi za obavljanje poslovne djelatnosti nužnog za osiguranje minimalnih uvjeta za uzdržavanje podnositelja i članova kućanstva; predmeti izuzeti od ovrhe; potpore zbog zbrinjavanja ratnih invalida i članova obitelji smrtno stradalih zatočenih ili nestalih hrvatskih branitelja; doplatak za djecu i novčani primici za opremu novorođenog djeteta; potpore zbog uništenja i oštećenja imovine zbog elementarnih nepogoda; potpore zbog uništenja i oštećenja imovine zbog ratnih događaja; te potpore za slučaj smrti radnika, potpore u slučaju smrti člana kućanstva radnika i potpore zbog neprekidnog bolovanja radnika, na koje se ne plaća porez na dohodak do iznosa propisanih poreznim propisom.

87 Čl. 15. st. 1. ZBPP-a. Ne utvrđuje se imovinsko stanje kad zahtjev podnosi dijete u postupku radi uzdržavanja, žrtva kaznenog djela nasilja u postupku za naknadu štete, osoba koja je korisnik pomoći za uzdržavanje u skladu s propisima iz sustava socijalne skrbi ili osoba koja je korisnik prava na opskrbninu prema Zakonu o pravima hrvatskih branitelja iz Domovinskog rata i članova njihovih obitelji i Zakonu o zaštiti vojnih i civilnih invalida rata. Dijete i korisnik pomoći za uzdržavanje ionako su oslobođeni na temelju čl. 16. ZSP-a, stoga je dio ovih odredbi suvišan. 
u gospodarske aktivnosti i ulaganje podrazumijeva mogućnost podmirenja sudskih pristojbi. ${ }^{90}$ Nacionalni je sud odluku donio na temelju apstraktnih kriterija i u potpunosti zanemario dokaze koje je podnositelj predložio. ${ }^{91}$ Sve je to, uz činjenicu da poljsko pravo poznaje mogućnost izmjene odluke o oslobođenju u slučaju promijenjenih okolnosti, dovelo do zaključka da je nacionalni sud povrijedio podnositeljevo pravo na pravično suđenje. ${ }^{92}$

U predmetu Jedamski i Jedamska protiv Poljske, ${ }^{93}$ ESLJP je ustanovio postojanje gotovo jednakih povreda. Podnositelji nisu oslobođeni plaćanja sudske pristojbe koja je, iako po iznosu jednaka onoj u predmetu Kreuz, u relevantnom razdoblju odgovarala iznosu pedeset prosječnih mjesečnih plaća u Poljskoj. ${ }^{94}$ ESLJP je i u ovom predmetu zamjerio činjenicu da je odluka donesena na temelju apstraktnih kriterija, bez uzimanja u obzir nemogućnosti podnositelja da raspolažu svojom imovinom. ${ }^{95}$ Posebno je ocijenjen pogrešnim navod da su podnositelji mogli pokrenuti više postupaka i tako rasporediti i lakše podnijeti troškove postupka. ${ }^{96}$

Istoga dana kad je donio odluku u predmetu Jedamski, ESLJP je utvrdio povredu članka 6. EKLJP-a i u predmetu Kniat protiv Poljske. ${ }^{97}$ Dvije su okolnosti koje ovaj predmet čine drukčijim od dva prethodno opisana. Prva je činjenica da je podnositeljica ponudila sudu platiti manji iznos od onog koji je bio određen, koji je ujedno mogla i platiti, no sud je to odbio. ${ }^{98}$ Druga je činjenica da je tužiteljica raspolagala prihodima koji nisu bili zanemarivi, ali je bila riječ o novcu dobivenom na ime podjele bračne stečevine. ${ }^{99}$ Nacionalni sud te je okolnosti u potpunosti zanemario. Osuđujući takvo postupanje, ESLJP je zaključio da nije bilo razumno očekivati da će podnositeljica novac uplaćen s naslova podjele bračne stečevine kao jedini prihod potrošiti na sudske pristojbe, umjesto da izgradi i osigura budućnost za sebe i svoju maloljetnu djecu. ${ }^{100}$ Time je jasno dao do znanja da se procjena prihoda i imovine ne može svesti na puke brojke i da se u obzir mora uzeti i širi društveni kontekst.

Način utvrđivanja imovinskog stanja od strane poljskog suda preispitan je i u predmetu Podbielski i PPU Polpure protiv Poljske ${ }^{101}$ o kojem je ESLJP također odlučivao isti dan kao i u prethodna dva predmeta. U tom je predmetu nacionalni sud odbio podnositelja osloboditi od plaćanja sudskih pristojbi. Unatoč insolventnosti i blokiranim računima, nacionalni je sud ocijenio da su podnositelj i njegovo društvo u relevantnom razdoblju prije donošenja presude imali dvostruko veći prihod od iznosa sudske pristojbe pa su mogli, očekujući parnicu, sačuvati

\footnotetext{
$90 \quad$ Ibid., $§ 62$.

91 Ibid., $§ \S 63 .-64$.

92 Ibid., §§ 65.-66.

$9373547 / 01$ od 26. srpnja 2005.

94 Ibid., § 47 .

95 Ibid., § 63.

96 Ibid., § 64 .

$97 \quad 71731 / 01$ od 26. srpnja 2005.

98 Ibid., § 17.

99 Ibid., §19.

100 Ibid., $§ 44$.

$10139199 / 98$ od 26. srpnja 2005.
} 
određeni iznos potreban za plaćanje sudskih pristojbi. ${ }^{102}$ ESLJP je osudio takvo retrospektivno sagledavanje imovinskog stanja i utvrdio povredu članka 6. EKLJP-a. ${ }^{103}$

Izložena stajališta ESLJP-a u vezi s kriterijem za oslobođenje od sudskih pristojbi mogu se sumirati na sljedeći način:

1. Iznos pristojbe mora se staviti u kontekst konkretnih životnih okolnosti osobe koja traži oslobođenje.

2. Imovinsko stanje mora se promatrati u odnosu na trenutak u kojem se oslobođenje traži, a ne retrospektivno.

3. Pri ocjeni imovinskog stanja u obzir treba uzeti i društvenu funkciju imovine koja se procjenjuje.

\subsubsection{Ocjena hrvatskog sustava}

Nakon donošenja novog ZBPP-a riješeni su brojni problemi koji su postojali u starom ZBPP-u, a na koje je zakonodavcu ukazao i Ustavni sud Republike Hrvatske. Kriteriji za odobravanje besplatne pravne pomoći značajno su pojednostavnjeni, ${ }^{104}$ a u određenoj mjeri su fleksibilizirani uvođenjem pravila o situacijama kad se imovinsko stanje uopće ne utvrđuje, pravila o prihodima i imovini koji se pri procjeni ne uzimaju u obzir te pravila o situacijama u kojima se, iznimno, uz opravdan razlog, pravna pomoć može odobriti i osobama čije imovinsko stanje prelazi zakonom propisane iznose. Na normativnoj razini, dakle, možemo a limine konstatirati da je zakonodavac u glavnini slijedio načela utvrđena u praksi ESLJP-a. U nekim postupcima imovinsko stanje je posve irelevantno, a kad se utvrđuje, utvrđuje se na temelju jasno postavljenih kriterija koji uzimaju u obzir i društvenu funkciju pojedinih izvora prihoda i imovine koji se i ne uzimaju u obzir, a kao relevantno razdoblje uzima se posljednjih dvanaest mjeseci prije podnošenja zahtjeva. Ipak, ovdje treba podsjetiti da je ESLJP ljestvicu postavio prilično visoko pa da ovako postavljen sustav i dalje može dovesti do nerazmjernih ograničenja prava na pristup pravosuđu.

Primjerice, Bogusława Kniat ni u Republici Hrvatskoj ne bi bila oslobođena sudskih pristojbi jer bi se njezin prihod ostvaren na temelju diobe bračne stečevine uzeo u opći izračun njezinih prihoda u posljednjih dvanaest mjeseci, a navod kako je taj novac predviđen za njezino

\footnotetext{
102 Ibid., $§ 59$.

103 Ibid., $§ 68$.

104 Vjerojatno najvažnija izmjena odnosi se na nekretnine u vlasništvu podnositelja zahtjeva i članova njegova kućanstva. Naime, u osnovnom tekstu starog ZBPP-a besplatna pravna pomoć nije mogla biti odobrena ako je podnositelj zahtjeva u vlasništvu imao nekretninu veću od tzv. zadovoljavajućeg stambenog prostora (bivši čl. 8. st. 1. t. c starog ZBPP-a), odnosno stan ili kuću veličine $35 \mathrm{~m}^{2}$ korisne površine za jednu osobu, uvećane za $10 \mathrm{~m}^{2}$ za svaku daljnju osobu, s maksimalnim mogućim odstupanjem do $10 \mathrm{~m}^{2}$ (bivši čl. 3. st. 18. starog ZBPP-a). Nakon što je Ustavni sud RH ukinuo bivši čl. 8. starog ZBPP-a, u ZID ZBPP/11 zadovoljavajućim su stambenim prostorom proglašeni jedini stan ili kuća koje podnositelj zahtjeva koristi zajedno $s$ članovima kućanstva za stanovanje (čl. 3. ZID ZBPP-a/11), bez obzira na njihovu površinu. U trenutačno važećem ZBPP-u dio nekretnine u kojoj živi podnositelj zahtjeva, a koji je nužan za ostvarenje osnovnih životnih potreba podnositelja zahtjeva i članova kućanstva, uopće se ne uzima u obzir pri procjeni imovinskog stanja (čl. 15. st. 2. t. 3. ZBPP-a), dok se ostale nekretnine uzimaju u obzir pri procjeni opće vrijednosti imovine koja ne smije prelaziti šezdeset proračunskih osnovica (čl. 14. st. 1. t. 2. ZBPP-a).
} 
dvoje maloljetne djece ne bi sam po sebi bio pravnorelevantan. ${ }^{105}$ Nadalje, ona ne bi pri podnošenju zahtjeva uopće imala prilike istaknuti društvenu svrhu tog prihoda jer u propisanom obrascu za to nije predviđen prostor. ${ }^{106}$ Tek kad bi ured državne uprave proveo ispitni postupak, ${ }^{107}$ podnositeljica bi dobila priliku istaknuti postojanje opravdanih razloga iz članka 14 . stavka 2. ZBPP-a. Pritom bi u načelu bilo moguće predložiti izvođenje istih dokaza koji su na raspolaganju u parničnom postupku, ${ }^{108}$ no njihovo bi pravilno i potpuno izvođenje, s obzirom na kratke rokove za donošenje rješenja, bilo teško zamislivo. ${ }^{109}$ Kratkoća roka još više dolazi do izražaja u situacijama u kojima teče rok za pokretanje nekog parničnog postupka. ${ }^{110}$ Stranka koja bi, u strahu od propuštanja roka, pokrenula parnični postupak prije podnošenja zahtjeva, našla bi se u bezizlaznoj situaciji. Naime, donošenje rješenja o pristojbi i njegovo prisilno izvršenje može odgoditi samo njezina obavijest da je nadležnom uredu podnesen zahtjev za oslobođenje, ${ }^{111}$ dok o zahtjevu za oslobođenje istaknutom u tužbi sud ne bi bio nadležan odlučivati. Stoga prethodno podnošenje zahtjeva može predstavljati nepremostivu zapreku onim strankama koje o toj mogućnosti i dužnosti nisu informirane. ${ }^{112}$

Nadalje, ne dovodeći u pitanje sposobnost spomenutih upravnih tijela da utvrđuju činjenice i ocjenjuju dokaze, smatramo da su sudovi ipak kompetentniji utvrđivati činjenice od kojih zavisi oslobođenje, a da je svakako svrsishodnije da odluku o oslobođenju donose upravo oni kao tijela nadležna za donošenje rješenja o pristojbi. To je racionalno rješenje ne samo zato što bi sud u imao dovoljno vremena za potpuno i pravilno ocjenjivanje svih relevantnih dokaza i odlučivanje o zahtjevu za oslobođenje prije nego što dođe u fazu donošenja rješenja o pristojbi, već i zato što se time značajno pojednostavljuje postupak. Naime, podacima o imovinskom

105 Zakonodavac je imao na umu djecu kad je iz prihoda koji se uzimaju u obzir isključio doplatak za djecu i jednokratne potpore za novorođeno dijete, ali ostala imovina morala bi biti stavljena u kontekst troškova liječenja ili drugih opravdanih troškova u smislu čl. 14. st. 3. ZBPP-a da bi je ured državne uprave uopće razmatrao.

106 Obrazac zahtjeva propisan je Pravilnikom o obrascu zahtjeva i rješenja o odobravanju korištenja pravne pomoći (Narodne novine, br. 64/2014; dalje: Pravilnik). Za razliku od situacija u kojima se imovno stanje ne utvrđuje (čl. 15. st. 1. ZBPP-a), na obrascu nije predviđen prostor u kojem bi podnositelji mogli istaknuti postojanje opravdanog razloga zbog kojeg ne mogu raspolagati ukupnim prihodima i imovinom (čl. 14. st. 2. t. 1. ZBPP-a).

107 Prema Zakonu o općem upravnom postupku (Narodne novine, br. 47/2009; dalje: ZOUP), ispitni postupak provodi se kad je to nužno radi utvrđivanja činjenica i okolnosti koje su bitne za razjašnjenje pravog stanja stvari, kad u postupku sudjeluju dvije stranke ili više njih s protivnim interesima te radi omogućivanja strankama ostvarenja i zaštite njihovih prava i pravnih interesa (čl. 51. st. 1. ZOUP-a). Pritom službena osoba može odrediti i izvođenje dokaza ako nađe da je to potrebno radi razjašnjenja stvari te upotpunjavanja činjeničnog stanja te izvođenje dokaza o činjenicama koje prije u postupku nisu bile iznesene ili još nisu utvrđene, a potrebne su radi utvrđivanja pravog stanja stvari (čl. 51. st. 2. ZOUP-a). U suprotnom bi se učinila bitna procesna povreda u smislu čl. 117. st. 1. t. 2. ZOUP-a. Ovako postupanje potvrdila je i Tanja Vukušić-Šerić, savjetnica u Gradskom uredu za opću upravu Grada Zagreba kojoj zahvaljujemo na pomoći.

108 Čl. 58. ZOUP-a.

109 Rok za donošenje rješenja petnaest je dana od dana urednog podnošenja zahtjeva (čl. 17. st. 2. ZBPP-a). Ministarstvo o žalbi odlučuje u roku od osam dana od primitka uredne žalbe (čl. 17. st. 6. ZBPP-a), a upravni spor može se pokrenuti u roku od 30 dana od dostave rješenja Ministarstva, sukladno čl. 24. st. 1. Zakona o upravnim sporovima (Narodne novine, br. 20/2010, 143/2012, 152/2014, 94/2016 i 29/2017).

110 Zakonodavac je, čini se, imao na umu takve situacije kad je propisao da o zahtjevu podnositelja, koji bi zbog isteka roka izgubio pravo na poduzimanje radnje za koju je podnio zahtjev, ured bio dužan odlučiti u roku koji mu omogućava pravodobno poduzimanje te radnje (čl. 17. st. 3. ZBPP-a). Ipak, teško je zamisliti da bi u tako kratkim rokovima bilo moguće saslušavati svjedoke, tražiti dostavu isprava i izvoditi druge dokaze za potrebe dokazivanja opravdanog razloga iz čl. 14. st. 2. i 3. ZBPP-a. Čl. 21. st. 1. i 2. ZBPP-a.

112 I ovom bi se problemu moglo doskočiti proširenjem mogućnosti pravnog informiranja i savjetovanja u okviru primarne pravne pomoći. Međutim, potpora pružateljima besplatne pravne pomoći posljednjih se godina pokazala nedovoljnom za pokrivanje njihovih stvarnih potreba. Za perspektivu pravnih klinika v. Preložnjak, B.; Brozović, J., The financial challenges of clinical legal education: an example from a Zagreb law clinic, International Journal of Clinical Legal Education, god. 23, br. 4, 2016., str. 157. 
stanju oduvijek je raspolagala Porezna uprava Ministarstva financija, ali prema trenutačnom uređenju plaćanje pristojbe nalaže sud, a o zahtjevu za oslobođenje odlučuje ured državne uprave. De facto o istoj stvari, ali s različitim ishodima, odlučuju dva različita tijela u dva različita trenutka, što može dovesti do toga da do oslobođenja dođe prekasno. Kad još uzmemo u obzir mogućnost podnošenja žalbe Ministarstvu te tužbe nadležnom upravnom sudu, broj se tijela koja sudjeluju u odlučivanju povećava. Osim što je takvo rješenje iracionalno u organizacijskom smislu, ono ima demotivirajući učinak na potencijalne korisnike besplatne pravne pomoći. Ako zahtjev za oslobođenje podnesu prije pokretanja parničnog postupka, odbijanje tog zahtjeva zbog ishitrene odluke ureda, koji u kratkom zakonskom roku ne može kvalitetno ocijeniti dokaze, može negativno utjecati na njihovu odluku o upuštanju u parnicu. S druge strane, ako zahtjev zbog nepoznavanja postupovnih pravila bude podnesen tek nakon što parnica otpočne, korisnici neće moći pravodobno zaustaviti ovršnost pravomoćnog rješenja o pristojbi.

Sve navedeno upućuje na zaključak da normativna fleksibilnost iz članka 14. stavka 2. ZBPP-a u primjeni može dovesti do u potpunosti suprotnih rezultata, što znači da je u osnovi iluzorna.

\subsection{OPSEG OSLOBOĐENJA}

Prije 2013. godine, ZPP je poznavao djelomično oslobođenje od plaćanja sudskih troškova, ali je ono zapravo obuhvaćalo oslobođenje od sudskih pristojbi, nasuprot potpunom oslobođenju koje je obuhvaćalo i oslobođenje od prethodnog snošenja parničnih troškova. ${ }^{113}$ Djelomično oslobođenje od sudskih pristojbi samo po sebi nije previđao ni ZPP ni ZSP. Ta je mogućnost uvedena tek donošenjem ZID starog ZBPP-a iz 2011., odnosno 1. siječnja 2013. kad su izmijenjene odredbe o oslobođenju od sudskih pristojbi stupile na snagu. Pravo na potpuno oslobođenje dobili su korisnici sustava socijalne skrbi, odnosno branitelji s pravom na opskrbninu, ali i osobe čiji ukupni dohodak i dohodak članova kućanstva po članu kućanstva iznose 50\% ili manje od mjesečnog iznosa najniže osnovice za obračun i plaćanje doprinosa za obvezna osiguranja, prema Zakonu o doprinosima za obvezna osiguranja. Ako bi podnositelj zahtjeva i članovi kućanstva imali veći prihod, opseg pomoći bi se smanjio za $10 \%$ za svako 10\%-tno povećanje iznosa, ali ne ispod $50 \%$ utvrđenog iznosa naknade za pravnu pomoć. ${ }^{114}$ Vrlo slično rješenje zadržao je i trenutačno važeći ZBPP, osim što je kao relevantnu osnovicu uzeo proračunsku osnovicu. ${ }^{115}$

113 Arg. ex bivši članak 175. ZPP-a. Čizmić, op. cit. u bilj. 48, str. 419.

114 Čl. 31. starog ZBPP-a.

115 Čl. 19. st. 3.-4. ZBPP-a. Također, više se ne spominju korisnici iz sustava socijalne skrbi, nego isključivo korisnici pomoći za uzdržavanje, no to ne zabrinjava, s obzirom na to da se može očekivati da će korisnici socijalne skrbi redovito ispunjavati uvjet imovinskog stanja. Istina, odlučivanje bi bilo ekonomičnije da su svi korisnici socijalne skrbi ex lege proglašeni korisnicima besplatne pravne pomoći. U svakom slučaju, vezivanjem prava na besplatnu pravnu pomoć uz proračunsku osnovicu htjelo se proširiti broj korisnika besplatne pravne pomoći (Konačni prijedlog ZBPP-a, str. 24.). U 2016. godini minimalna mjesečna osnovica iz čl. 20. Zakona o doprinosima (Narodne novine, br. 84/2008, 152/2008, 94/2009, 18/2011, 22/2012, 144/2012, 148/2013, 41/2014, 143/2014 i 115/2016) iznosila je 2.163,34 kune, za razliku od proračunske osnovice iz čl. 21. Zakon o izvršavanju Državnog proračuna Republike Hrvatske za 2016. godinu (Narodne novine, br. 26/2016) koja je iznosila 3.326,00 kuna. Procjena iz Konačnog prijedloga ZBPP-a, čini se, nije bila pogrešna. 
Spomenute reforme nisu nevažne, s obzirom na to da je i o pitanju djelomičnog oslobođenja odlučivao i ESLJP. Tako je u nizu predmeta osudio izostanak djelomičnog oslobođenja od plaćanja sudskih pristojbi, a u nekima od njih podnositelji su izričito tražili takvo oslobođenje. U predmetu Polejowski protiv Poljske, ${ }^{116}$ ESLJP je osudio činjenicu da poljski sud uopće nije razmotrio mogućnost djelomičnog oslobođenja od plaćanja pristojbi iako je iznos pristojbe $u$ konkretnom slučaju dvadeset puta nadilazio mjesečni prihod podnositelja. ${ }^{117} \mathrm{U}$ već spomenutom predmetu FC Mretebi nacionalni sud u potpunosti je zanemario prijedloge podnositelja da ga se djelomično oslobodi od plaćanja sudske pristojbe ili da mu se barem odobri obročno plaćanje. ${ }^{118}$ Slično je učinjeno i u predmetu Podbielski, što je ESLJP također osudio. ${ }^{119}$ Konačno, i u predmetu Kniat odbijanje nacionalnog suda da odobri djelomično oslobođenje nije naišlo na odobravanje ESLJP-a. ${ }^{120}$

Stoga svakako treba pozdraviti odluku zakonodavca da i u ZBPP-u omogući djelomično oslobođenje od sudskih pristojbi. Također, treba pozdraviti i povećanje osnovice koja se uzima u obzir pri ocjeni prihoda. ${ }^{121}$ Međutim, čini se da i tako postavljen imovinski cenzus i dalje iz kruga korisnika kojima se odobrava (potpuno) oslobođenje isključuje velik broj građana. Primjerice, samohrana majka jednog djeteta koja ima prosječnu hrvatsku plaću od približno 5.500,00 kuna i samo jednu nekretninu teško da se može smatrati dobrostojećom osobom iako ne bi mogla ostvariti pravo na potpuno oslobođenje. Ista osoba s prosječnom plaćom na području Grada Zagreba u približnom iznosu od 6.500,00 kuna uopće ne bi zadovoljavala imovinski cenzus za oslobođenje. Možemo li, dakle, zaključiti da će navedene osobe imati motiva voditi parnične postupke ako će pritom morati platiti sudsku pristojbu u iznosu od nekoliko tisuća kuna? Tim više što hrvatsko pravo ne omogućuje plaćanje pristojbe u mjesečnim obrocima. S obzirom na to da smo već utvrdili da je u postojećem uređenju gotovo nemoguće $s$ uspjehom se pozivati na opravdani razlog iz članka 14. stavka 2. ZBPP-a, može se očekivati da će ovakvo uređenje velikom broju građana ograničiti ili čak onemogućiti pristup pravosuđu. To, naravno, može dovesti do novih povreda članka 6. EKLJP-a i odgovornosti Republike Hrvatske pred ESLJP-om.

\subsection{PRAVNE POSLJEDICE NEPLAĆANJA SUDSKIH PRISTOJBI}

Prije donošenja ZSP-a, jugoslavenski Osnovni zakon o sudskim pristojbama i stari ZSP predviđali su posljedice neplaćanja koje se mogu usporediti s posljedicama koje propisuje trenutačno važeći ZSP. Neplaćanje pristojbe nije utjecalo na tijek parnice, nego je dovodilo do

116 38299/03 od 4. ožujka 2008.

117 Ibid., § 36 . Ovo je posebno zanimljivo stoga što je nacionalni sud svoju odluku utemeljio na zaključcima koji nisu proizlazili iz priloženih dokaza (ibid., § 35.). Naime, podnositelj je u svojem zahtjevu za oslobođenje podnio dokaze iz kojih proizlazi da raspolaže neto prihodom od svega 48 eura. Poljski sud smatrao je nemogućim njegovo preživljavanje s toliko niskim prihodom pa je zaključio da ima alternativne izvore prihoda koji mu, među ostalim, omogućuju i plaćanje sudske pristojbe (ibid., § 8.).

118 FC Mretebi, op. cit. u bilj. 55, § 26. I takvo je postupanje ESLJP osudio (ibid., § 47.).

119 Podbielski, op. cit. u bilj. 121, §67.

120 Kniat, op. cit. u bilj. 98, §43.

121 Umjesto osnovice za izračun obveznih osiguranja uzima se u obzir proračunska osnovica koja je u proteklim godinama bila viša za gotovo $1.000,00$ kuna. 
prisilnog izvršenja rješenja o pristojbi. ${ }^{122}$ Donošenjem prvog ZSP-a nakon osamostaljenja Republike Hrvatske, ovo je rješenje promijenjeno na način da neplaćanje pristojbe dovodi do zastoja u postupku sve dok iznos pristojbe ne bude podmiren. Izmjenama reformske 2003. godine to je rješenje napušteno. ${ }^{123}$ Otada važi gotovo jednako rješenje prema kojem neplaćanje pristojbe dovodi do donošenja rješenja o pristojbi, a po pravomoćnosti tog rješenja i do ovrhe, ${ }^{124} \mathrm{~s}$ time da se prvo ovršno rješenje dostavlja Financijskoj agenciji, ${ }^{125}$ a poslije i Poreznoj upravi. ${ }^{126}$ Time je donekle olakšan položaj tužitelja koji pokreću postupak jer neplaćanje pristojbe neće spriječiti donošenje meritorne odluke.

Jesu li time spriječene potencijalne povrede članka 6. EKLJP-a? Činjenica je da je u svim predmetima u kojim je utvrđivana povreda posljedica bilo ili odbacivanje ili presumpcija da je pojedina parnična radnja (tužba ili žalba) povučena. Ovakve razlike u pojedinim zakonodavstvima dovele su Ustavni sud Crne Gore, koji je ocjenjivao ustavnost odredbi o prisilnom izvršenju rješenja o pristojbi koje u velikoj mjeri odgovaraju hrvatskom rješenju, na zaključak da se takvim postupanjem ne ograničava pravo na pristup pravosuđu. ${ }^{127}$ Međutim, s takvim se stajalištem ne možemo složiti.

Spoznaja da je za vođenje parničnog postupka potrebno platiti određeni novčani iznos itekako je od utjecaja na ponašanje stranaka. Štoviše, jedna od temeljnih funkcija sudskih pristojbi i jest demotivacija obijesnih parničara koji parnični postupak ne shvaćaju dovoljno ozbiljno. ${ }^{128}$ Međutim, ono što ne smije biti rezultat obveze plaćanja sudske pristojbe jest da od parničnog postupka odustanu one stranke koje doista trebaju zaštitu svojih subjektivnih građanskih prava. S time u vezi, prisilno izvršenje rješenja o pristojbi u konkretnim okolnostima može za stranku koja nije u stanju podmiriti dužni iznos predstavljati veći teret nego što bi to predstavljao eventualni zastoj postupka, posebno ako bi time bila ugroženo osnovno uzdržavanje stranke, odnosno članova njezina kućanstva. Prema tome, sama činjenica da neplaćanje pristojbe ne sprječava donošenje meritorne odluke nije dovoljna da bi se isključila svaka mogućnost povrede strankina prava na pristup pravosuđu pa su načela utvrđena u praksi ESLJP-a primjenjiva i u ovakvom uređenju. Sudska pristojba i dalje u konkretnoj situaciji može dovesti do toga da stranka bude prisiljena odustati od pojedine parnične radnje što ograničava njezin pristup pravosuđu.

\footnotetext{
122 Usp. čl. 38.-42. Osnovnog zakona o sudskim pristojbama i čl. 40.-45. starog ZSP-a. Zanimljivo, oba su zakona kao posljedicu neplaćanja poznavala tzv. kaznenu taksu (pristojbu) koja je iznosila 50\% iznosa pristojbe, a koju je pristojbeni obveznik bio dužan podmiriti zajedno s osnovnim iznosom, pod prijetnjom prisilnog izvršenja.

123 Prema bivšem čl. 9. ZSP-a, sud nije postupao u onim predmetima u kojima nije plaćena pristojba, ali se to pravilo nije odnosilo na one vrste postupaka u kojima je određeno hitno rješavanje.

124 I ove su odredbe bile predmet ocjene ustavnosti od strane Ustavnog suda RH koji je u rješenju od 11. srpnja 2007., posl. br. 11. U-I-500/2004 utvrdio: “(...) polazeći od članaka 39. i 39.a. Zakona o sudskim pristojbama propisane zaštite u postupku radi naplate neplaćene pristojbe, da, unatoč tome što strankama nije osigurano sudjelovanje i u postupku donošenja rješenja nadležne ispostave porezne uprave, osporena odredba nije u nesuglasnosti s ustavnim odredbama koje navodi predlagatelj."

125 Čl. 40. st. 1. ZSP-a.

126 Čl. 40. st. 2. ZSP-a.

127 Vukčević, I.; Marković, M., Pravo na pristup sudu i sudske takse: praksa Evropskog suda za ljudska prava i Ustavnog suda Crne Gore, Journal of Legal and Social Studies in South East Europe, 2015., str. 290.

128 Hodges, C.; Vogenauer, S.; Tulibacka, M., The Costs and Funding of Civil Litigation - A Comparative Perspective, Hart Publishing, Oxford and Porland, 2010., str. 4.-5.
} 


\section{EMPIRIJSKI PODACI O OSLOBOĐENJU OD SUDSKIH PRISTOJBI}

Da bismo mogli donijeti precizne zaključke o tome u kojoj mjeri postojeće zakonodavno uređenje doista pridonosi ostvarenju prava na pristup pravosuđu, bilo bi potrebno napraviti šire istraživanje sa studijama slučajeva, što bi nadilazilo opseg ovog rada. Stoga smo, u izostanku takvog uvida u pojedine predmete, od nadležnih tijela zatražili podatke koji mogu upozoriti na trendove te, s visokim stupnjem vjerojatnosti, potvrditi ili opovrgnuti neke od teza istaknutih u ovom radu.

Podatke o broju građana koji su ostvarili pravo na oslobođenje od sudskih pristojbi Ministarstvo objavljuje jedanput na godinu na svojim mrežnim stranicama u okviru izvješća o ostvarivanju prava na besplatnu pravnu pomoć i utrošku sredstava. ${ }^{129}$ Iz njih je vidljivo (Graf 1) da je prve godine primjene novog režima ZBPP-a karakterizirao prilično nizak broj oslobođenja od svega tisuću oslobođenja po godini, da bi se u 2015. godini uvećao gotovo šest puta:

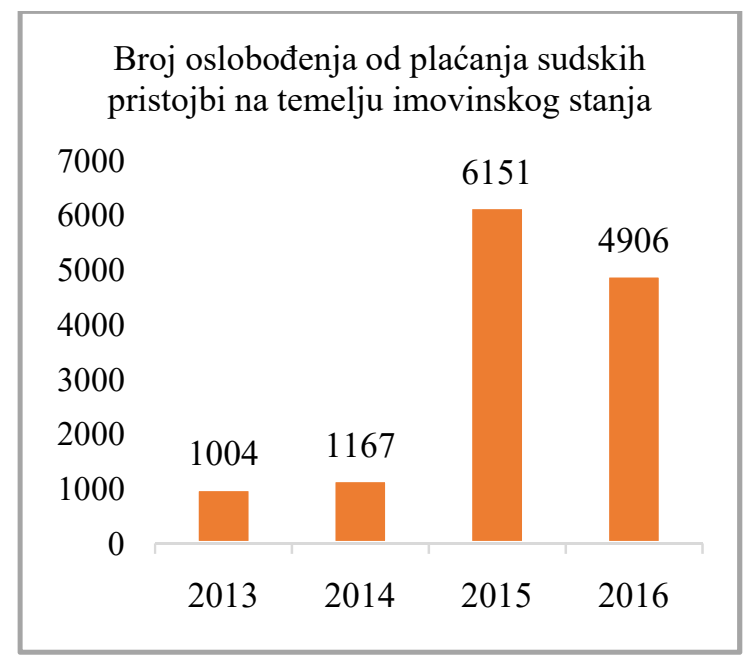

\section{Graf 1}

Međutim, u 2016. godini taj je broj ponovno pao te se stabilizirao na nešto manje od pet tisuća predmeta. Iako se broj oslobođenja ne može smatrati zanemarivim, sam po sebi ne govori mnogo o tome jesu li zadovoljene sve potrebe građana. Stoga smo zatražili podatke od Financijske agencije koja provodi ovrhu na novčanim sredstvima na temelju rješenja o pristojbi. ${ }^{130}$ U svojoj evidenciji Financijska agencija bilježi broj zaprimljenih rješenja o pristojbama, ${ }^{131}$ broj rješenja na temelju kojih je uspješno provedena ovrha (uz podatak o tome je li ovrha odmah

\footnotetext{
129 Izvješća su dostupna na sljedećoj poveznici: https://pravosudje.gov.hr/pristup-informacijama-6341/strategije-planovi-iizvjesca/izvjesce-o-ostvarivanju-prava-na-besplatnu-pravnu-pomoc-i-utrosku-sredstava/6723 (15. travnja 2017.).

130 Zahvaljujemo kolegici Vinki Ilak, višem specijalistu za pravnu podršku u Financijskoj agenciji, Sektoru usluga za državu, Centru za prisilnu naplatu i predstečajne nagodbe, koja nam je omogućila i olakšala pristup dostupnim statističkim podacima.

131 U smislu čl. 40. st. 1. ZSP-a.
} 
60

provedena), kao i broj rješenja koja su, zbog neuspješne naplate u roku od godine dana, dostavljena nadležnoj Poreznoj upravi na provođenje ovršnog postupka. ${ }^{132}$ Podaci se vode odvojeno za pravne osobe, fizičke osobe koje obavljaju gospodarsku djelatnost te druge fizičke osobe. S obzirom na to da korisnici besplatne pravne pomoći mogu biti samo fizičke osobe, najprije ćemo prikazati njihove podatke.

Već prvi pogled na podatke o rješenjima o pristojbi koja su u postupku izravne naplate (Graf 2) pokazuje očit kontinuirani rast u proteklih nekoliko godina:

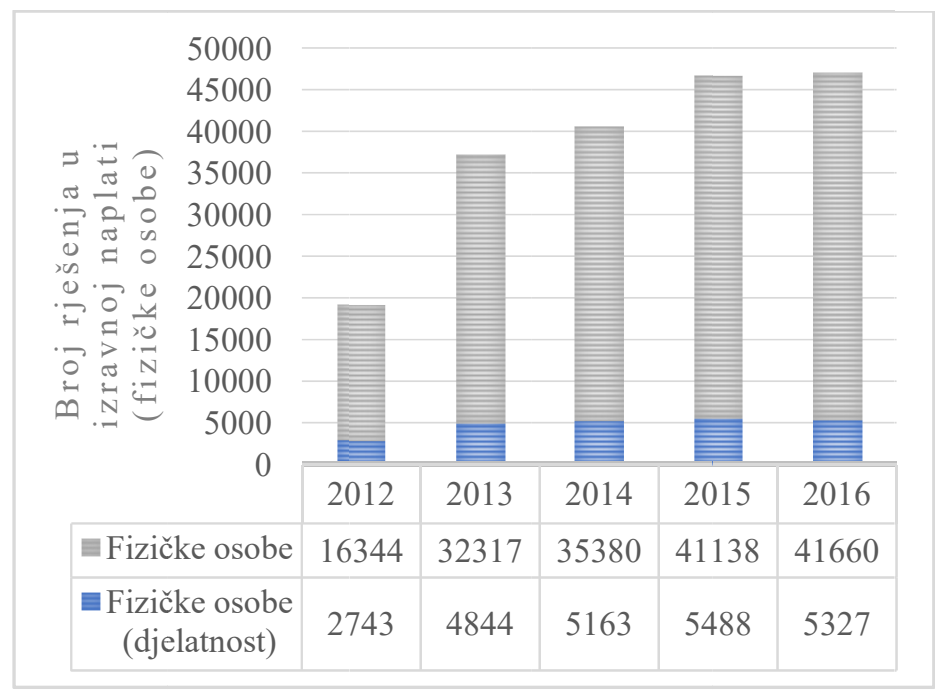

\section{Graf 2}

Svakako, sama činjenica da je rješenje o pristojbi dostavljeno Financijskoj agenciji na izravnu naplatu ne znači da na računu nije bilo dostatnih sredstava. Dio ovršenika - pristojbenih obveznika zasigurno je svojevoljno odlučio odbiti platiti dužni iznos pristojbe. Može se pretpostaviti da je u njihovu slučaju rješenje o pristojbi izvršeno odmah. Nadalje, neka rješenja izvršena su tijekom godine, višekratnim djelomičnim prijenosima sredstava. Međutim, najveći dio izravnih naplata ipak nije dovršen uspješno, kako to pokazuju sljedeći podaci (Graf 3): 


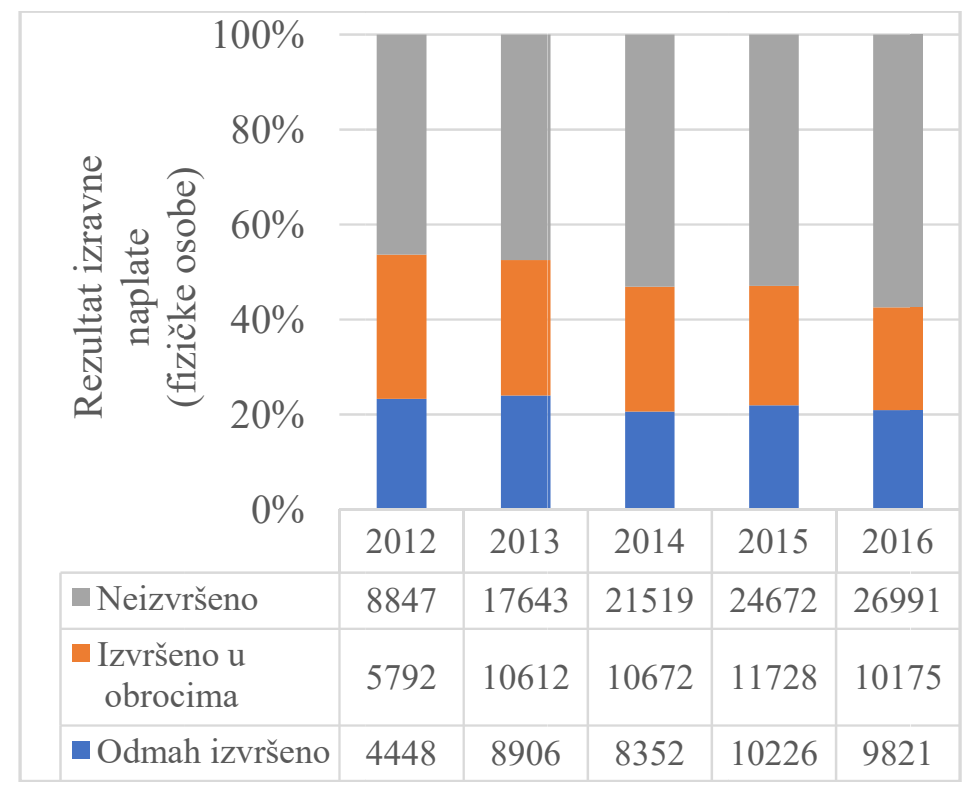

\section{Graf 3}

Kad se ovi podaci usporede s podacima Ministarstva, primjećujemo da broj neizvršenih rješenja o pristojbi u pojedinim godinama umnogome nadilazi broj odobrenih oslobođenja: $u$ 2013. više od sedamnaest puta, u 2014. više od osamnaest puta, u 2015. više od četiri puta, a u 2016. nešto manje od pet puta. Iako se broj oslobođenja prema odredbama ZBPP-a u proteklim godinama povećao, što najvjerojatnije treba pripisati većoj informiranosti građana o sustavu oslobođenja, čini se da je taj broj i dalje premalen. To bi se moglo objasniti, ponajprije, nedovoljnom informiranošću građana zbog koje svoje zahtjeve za oslobođenje ne podnose nadležnom tijelu ili to čine prekasno, te činjenicom da ovako uređen postupak u cjelini ne omogućava na adekvatan način iznošenje činjenica koje bi opravdale oslobođenje kad se to $a$ limine ne čini opravdanim. Nadalje, činjenica da velik broj rješenja nije izvršen odmah, nego u obrocima, mogla bi se tumačiti kao pokazatelj da trenutačno postavljeni iznosi sudskih pristojbi nisu prilagođeni mogućnostima građana.

Međutim, ono što najviše zabrinjava podaci su o broju rješenja dostavljenih Poreznoj upravi koji pokazuju da velik broj fizičkih osoba nema dovoljno likvidne imovine za podmirenje troškova sudskih pristojbi (Graf 4): ${ }^{133}$ 


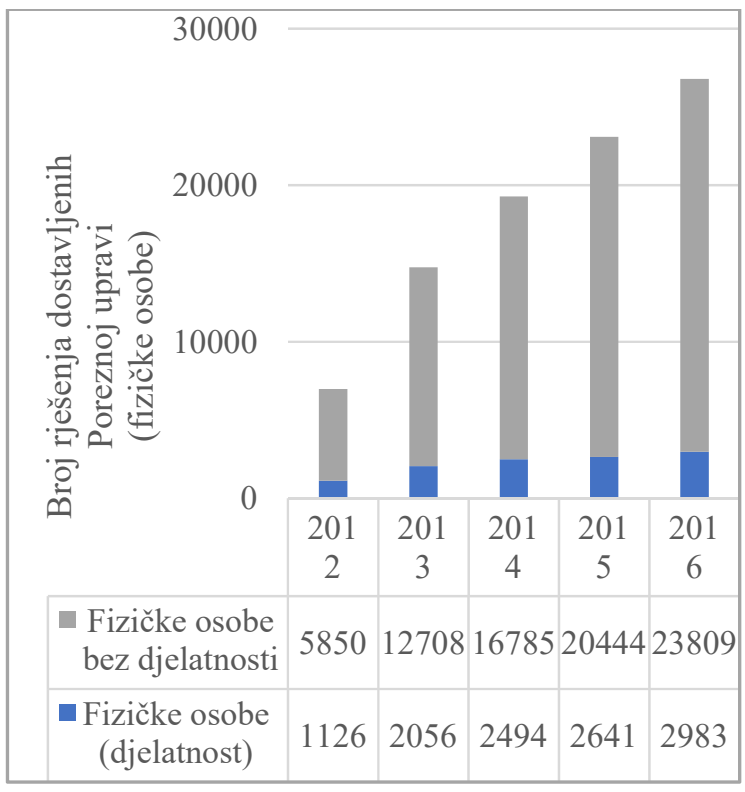

\section{Graf 4}

Taj nerazmjer između broja oslobođenja i broja rješenja o pristojbi u vezi s neuspješnom izravnom ili drugom prisilnom naplatom, dokazuje da trenutačno postavljeni sustav oslobođenja ne ispunjava svoju zakonom zamišljenu svrhu.

Kad je riječ o pravnim osobama, podaci Financijske agencije ne razlikuju profitne od neprofitnih osoba iako je očekivano da velika većina tih pravnih osoba ima gospodarski karakter. Podaci o izravnoj naplati (Graf 5), kao i podaci o broju rješenja dostavljenih Poreznoj upravi (Graf6) pokazuju da i velik broj pravnih osoba ima teškoća s plaćanjem sudskih pristojbi: 


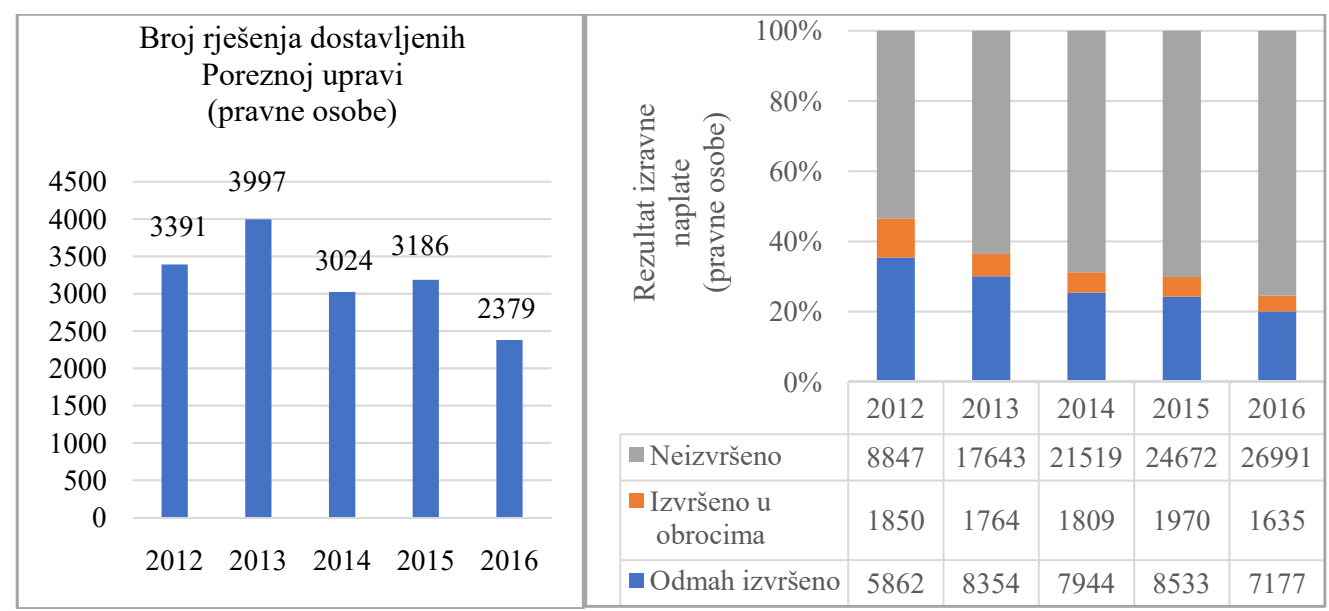

Graf 5

Graf 6

Stoga bi i pravila o oslobođenju i besplatnoj pravnoj pomoći uopće, koja kao korisnike predviđaju samo fizičke osobe, valjalo preispitati, posebno u svjetlu gospodarskih ciljeva koji se žele postići.

\section{ZAKLJUČAK}

Zakonske izmjene pravila o oslobođenju od sudskih pristojbi nisu rezultirale željenim rezultatima. Stvoren je složen sustav koji velikom broju građana onemogućuje ravnopravno sudjelovanje u parničnom postupku. Iako su uredi državne uprave specijalizirana tijela čiju neovisnost u postupanju nadziru Ministarstvo i nadležni upravni sud, u organizacijskom smislu iracionalno je angažiran značajno veći broj državnih tijela nego što je to bio slučaj u prijašnjem uređenju. Također, čini se da mehanizmi poput onog iz članka 14. stavka 2. ZBPP-a, čija je svrha bila fleksibilizacija odobravanja besplatne pravne pomoći, u takvom sustavu ne mogu postići svoju svrhu. Uredi državne uprave nemaju kapaciteta za pravodobno provođenje postupka, zbog čega stranke nemaju priliku da se tijekom odlučivanja o njihovu zahtjevu za oslobođenje doista utvrde sve pravnorelevantne činjenice. Rezultat je ili da zahtjevu ne bude udovoljeno ili da to bude učinjeno prekasno. S druge strane, sudovi su nemoćni u slučaju stranaka koje zbog neznanja svoj zahtjev za oslobođenje podnose sudu, najčešće uz tužbu, koji se potom odbacuje zbog apsolutne nenadležnosti. Oni bi, zbog instruktivne naravi rokova iz ZSP-a, mogli odgoditi donošenje rješenja o pristojbi, pružajući stranci tako priliku da zahtjev podnese nadležnom tijelu, no obveza plaćanja pristojbe već bi nastala i dospjela, što znači da eventualno naknadno udovoljavanje zahtjevu ne može stranku osloboditi plaćanja te pristojbe.

Postojanje problema potvrđuju i empirijski podaci prikazani u ovom radu. Velikom broju građana pokretanje postupka i dalje predstavlja značajan financijski teret, što može djelovati demotivirajuće na pokretanje parničnih postupaka. To se ne odnosi samo na korisnike soci- 
jalne skrbi, ${ }^{134}$ nego i na pripadnike tzv. srednjeg sloja čiji prihodi nadilaze minimum potreban za vlastito uzdržavanje i uzdržavanje članova kućanstva, ali koji u uvjetima nepovoljne gospodarske situacije i zaduženosti velikim dijelom svojih prihoda uopće ne mogu raspolagati.

Kako se suočiti sa svim ovim problemima? Ponajprije trebalo bi učiniti ono što do današnjeg dana nikad nije bilo učinjeno, a to je sveobuhvatna analiza sustava sudskih pristojbi u kojoj bi se preispitali njihovi iznosi na način da se stave u međuodnos sa stvarnim mogućnostima građana, ali i potrebama pravosuđa. Bez toga nije moguće uspostaviti pravičan sustav sudskih pristojbi koji bi ispunjavao sve svrhe koje se od njega redovito očekuju (sprječavanje obijesnog parničenja te razmjerno sudjelovanje u financiranju pravosudnog sustava). Svakako, paralelno bi valjalo uspostaviti učinkovit sustav oslobođenja od sudskih pristojbi.

Učinkovitost tog sustava treba se odraziti već i na izboru tijela nadležnog za odlučivanje o oslobođenju. Velik dio problema mogao bi se riješiti tako da odlučivanje o oslobođenju ponovno vrati u nadležnost sudova koji su ujedno nadležni za donošenje rješenja o pristojbi. Sud bi si tada, prije nego što se uopće upušta u donošenje rješenja o pristojbi te njegovo dostavljanje na izravnu naplatu Financijskoj agenciji, mogao za odlučivanje o zahtjevu i utvrđivanje svih važnih činjenica uzeti onoliko vremena koliko mu je to potrebno, bez straha da će stranka zbog proteka vremena izgubiti određena prava. Pritom bi mogao izvoditi dokaze na jednak način kako utvrđuje i druge činjenice u postupku. Može se očekivati da bi ovakvo rješenje naišlo na otpor, s obzirom na to da se sucima (uvjetno rečeno) na teret stavlja dodatna aktivnost koja nije u neposrednoj vezi s odlučivanjem o meritumu. Međutim, valja imati na umu da se pitanje oslobođenja ne može smatrati pukim administriranjem, nego dijelom pružanja pravne zaštite što znači da mu treba biti posvećena jednaka pozornost. Alternativno, rad sudova i upravnih tijela morao bi se uskladiti da stranke, koje nisu dovoljno informirane o svojim pravima, ne bi iz formalnih razloga ostale bez oslobođenja koje im zakon jamči. ${ }^{135}$ Općenito bi trebalo poraditi na dodatnom informiranju građana, što se može postići dodatnim ulaganjem u sustav primarne besplatne pravne pomoći. Trendovi u financiranju tog sustava, nažalost, idu u suprotnom smjeru. ${ }^{136}$

Naposljetku, valjalo bi razmisliti da se uvede mogućnost oslobođenja, ali i besplatne pravne pomoći uopće, i za neke kategorije pravnih osoba. To je osobito važno u kontekstu prekogranične pravne zaštite u okviru Europske unije koja je, čini se, počela nametati državama članicama takvu obvezu. To se svakako odnosi na neprofitne pravne osobe, ali ne treba beziznimno isključiti i one koje imaju gospodarski karakter ako bi iz okolnosti slučaja postojala potreba za njihovim oslobođenjem.

Velik dio predloženih rješenja zahtijevao bi ulaganje dodatnih proračunskih sredstava, ali u uvjetima u kojima Republika Hrvatska za besplatnu pravnu pomoć izdvaja gotovo tri i pol

134 Državni zavod za statistiku 2012. objavio je podatke o broju punoljetnih korisnika socijalne skrbi. Na 31. prosinca 2011. u Hrvatskoj je bilo ukupno 74.127 osoba koje nemaju dovoljno sredstava za život, odnosno ukupno 49.229 osoba koje nemaju dovoljno prihoda za uzdržavanje. Podaci objavljeni na: www.dzs.hr/Hrv-Eng/publication/2012/08-04-01-01-2012.htm (28. travnja 2017.).

135 Odredba prema kojoj oslobođenje od plaćanja sudskih pristojbi djeluje od dana kada je uredu podnesen zahtjev za odobravanje pravne pomoći i vrijedi za sve podneske i radnje za koje je nastala obveza plaćanja sudskih pristojbi toga dana ili poslije (čl. 19. st. 8. ZBPP-a) u potpunosti odgovara bivšem čl. 13. ZSP-a. Međutim, pri unošenju ove odredbe u ZBPP nije se vodilo računa o tome da odluku o oslobođenju više ne donosi sud što dovodi do niza opisanih problema (v. supra 2.3.3. Ocjena hrvatskog sustava).

136 Preložnjak, Brozović, op. cit. u bilj. 113. 
puta manje od europskog prosjeka ${ }^{137}$ čini se da zakonodavcu ne preostaje previše izbora. Republika Hrvatska mora osvijestiti da pravo na pristup pravosuđu nema alternativu. Ako to ne učini, postoje međunarodni mehanizmi u okviru Vijeća Europe i Europske unije koji će sustav potaknuti na promjene.

\section{LITERATURA}

1. Cutvarić, M., Naknada troškova parničnog i ovršnog postupka i obračun PDV-a, Računovodstvo i financije, br. 12/2014.

2. Čizmić, J., O pružanju besplatne pravne pomoći, Zbornik Pravnog fakulteta Sveučilišta u Rijeci, god. 31, br. 1, 2010.

3. Hodges, C.; Vogenauer, S.; Tulibacka, M., The Costs and Funding of Civil Litigation - A Comparative Perspective, Hart Publishing, Oxford and Porland, 2010.

4. Jelinić, Z.; Knol Radoja, K., Analiza hrvatskoga sustava besplatne pravne pomoći u građanskim stvarima u svjetlu dosadašnje prakse Europskoga suda za ljudska prava, Pravni vjesnik, god. 30, br. 2, 2014.

5. Johnsen, J.; Stawa, G.; Uzelac, A., Ocjena hrvatskog Zakona o besplatnoj pravnoj pomoći i njegove provedbe u praksi, Centar za ljudska prava, Zagreb, 2011., http://www.alanuzelac.from.hr/pubs/ E15-Evaluation-CLAA2010hrv.pdf (26. travnja 2017.)

6. Legal aid: procedures for grant - inability to pay court fees - arts 6(1) and 13, European Human Rights Law Review, br. 5, 2008.

7. Palmer, E. et al. (ur.), Access to Justice Beyond the Policies and Politics of Austerity, Hart Publishing, Oxford and Portland, Oregon, 2016.

8. Preložnjak, B.; Brozović, J., The financial challenges of clinical legal education: an example from a Zagreb law clinic, International Journal of Clinical Legal Education, god. 23, br. 4, 2016.

9. Roth, M., Litigating in Ausrtia - Are Costs and Fees Worth it?, u: Reimann, M. (ur.), Cost and Fee Allocation in Civil Procedure: A Comparative Study, Springer, Dordrecht-Heidelberg-London-New York, 2012.

10. Settem, O. J., Applications of the 'Fair Hearing' Norm in ECHR Article 6(1) to Civil Proceedings With Special Emphasis on the Balance Between Procedural Safeguards and Efficiency, Springer, Cham-Heidelberg-New York-Dordrecht-London, 2016.

11. Slonina, M., Verfahrenshilfe für juristische Personen: Ein Weihnachtsgeschenk des EuGH?, ecolex, br. 5/2011.

12. Susi, M., Application of the Access to Court Doctrine by the European Court of Human Rights: Estonia's Concept of Comprehensive Court Protection, German Yearbook of International Law, god. 52, 2009.

13. Triva, S.; Dika, M., Građansko parnično procesno pravo, Sedmo izmijenjeno i dopunjeno izdanje, Narodne novine, Zagreb, 2004.

14. Uzelac, A., Pravo na pravično suđenje u građanskim predmetima: nova praksa Europskog suda za ljudska prava i njen utjecaj na hrvatsko pravo i praksu, Zbornik Pravnog fakulteta u Zagrebu, god. 60, br. 1, 2010.

137 CEPEJ izvješće, op. cit. u bilj. 35, str. 72. To se odnosi na besplatnu pravnu pomoć i u kaznenim predmetima, što znači da je situacija još gora kad se uzmu u obzir samo podaci za besplatnu pravnu pomoć u građanskim stvarima. 
15. Uzelac, A.; Preložnjak, B., The Development of Legal Aid Systems in the Western Balkans. A Study of Controversial Reforms in Croatia and Serbia, Kritisk Iuss, Utgitt av Rettspolitisk Forening (Liber amicorum - Jon T. Johnsen), god. 38, br. 3-4, 2012.

16. Vukčević, I.; Marković, M., Pravo na pristup sudu i sudske takse: praksa Evropskog suda za ljudska prava i Ustavnog suda Crne Gore, Journal of Legal and Social Studies in South East Europe, 2015.

17. Zaccarono, G., Consequences of Accession of the EU to the ECHR on the Jurisdictional Architecture of Europe [article] Law of Ukraine: Legal Journal, god. 2013, br. 3, 2013.

\section{POPIS PROPISA}

1. Austrija: Gesetz über das gerichtliche Verfahren in bürgerlichen Rechtsstreitigkeiten (Zivilprozessordnung - ZPO) od 1. kolovoza 1895. (RGBl. Nr. 113/1895), posljednji put izmijenjen 16. prosinca 2014. (BGBl. I Nr. 92/2014).

2. Austrija: Gerichtsgebührengesetz (dalje: austrijski GGG) od 14. prosinca 1984. (BGBl. Nr. 501/1984) posljednji put izmijenjen 7. svibnja 2012. (BGBl. I Nr. 35/2012).

3. Direktiva Europskog parlamenta i Vijeća 2014/23/EU od 26. veljače 2014. o dodjeli ugovorâ o koncesiji (Službeni glasnik L 94, 28. ožujka 2014., str. 1.-64., celex 32014L0023).

4. Direktiva Europskog parlamenta i Vijeća 2014/24/EU od 26. veljače 2014. o javnoj nabavi i o stavljanju izvan snage Direktive 2004/18/EZ (Službeni glasnik L 94, 28. ožujka 2014., str. 65.-242., celex 3A32014L0024).

5. Direktiva Europskog parlamenta i Vijeća 2014/25/EU od 26. veljače 2014. o nabavi subjekata koji djeluju u sektoru vodnog gospodarstva, energetskom i prometnom sektoru te sektoru poštanskih usluga i stavljanju izvan snage Direktive 2004/17/EZ (Službeni glasnik L 94, 28. ožujka 2014., str. 243.-374., celex 32014L0025).

6. Direktiva Vijeća 2003/8/EZ od 27. siječnja 2003. o unapređenju pristupa pravosuđu u prekograničnim sporovima utvrđivanjem minimalnih zajedničkih pravila o pravnoj pomoći u takvim sporovima (Službeni glasnik L 26, 31. ožujka 2003., str. 41.- 47., posebno izdanje na hrvatskom jeziku: Poglavlje 19, Volumen 3, str. 105.- 111., celex 32003L0008).

7. Europska konvencija za zaštitu ljudskih prava i temeljnih sloboda (Narodne novine, Međunarodni ugovori, br. 18/1997, 6/1999, 14/2002, 13/2003, 9/2005, 1/2006 i 2/2010).

8. Osnovni zakon o sudskim taksama (Službeni list FNRJ, br. 16/1960, Službeni list SFRJ, br. 10/1965, 15/1965 i 8/1969 i Narodne novine, br. 52/1971 i 52/1973).

9. Povelja o temeljnim pravima (Službeni glasnik C 364, 18. prosinca 2000., str. 1.-22., celex: 12007P).

10. Pravilnik o obrascu zahtjeva i rješenja o odobravanju korištenja pravne pomoći (Narodne novine, br. 64/2014).

11. Uredba Vijeća (EZ) br. 44/2001 od 22. prosinca 2000. o nadležnosti, priznavanju i izvršenju sudskih odluka u građanskim i trgovačkim stvarima (Službeni glasnik L 12, 16. siječnja 2001., str. 1.-23., celex 32001R0044).

12. Ustavni zakon o Ustavnom sudu RH (Narodne novine, br. 99/1999, 29/2002 i 49/2002).

13. Zakon o besplatnoj pravnoj pomoći (Narodne novine, br. 143/2013).

14. Zakon o besplatnoj pravnoj pomoći (Narodne novine, br. 62/2008).

15. Zakon o doprinosima (Narodne novine, br. 84/2008, 152/2008, 94/2009, 18/2011, 22/2012, 144/2012, 148/2013, 41/2014, 143/2014 i 115/2016). 
16. Zakon o izmjenama i dopunama Zakona o besplatnoj pravnoj pomoći (Narodne novine, br. 81/2011).

17. Zakon o izmjenama i dopunama Zakona o parničnom postupku (Narodne novine, br. 25/2013).

18. Zakon o izmjenama i dopunama Zakona o sudskim pristojbama (Narodne novine, br. 157/2013).

19. Zakon o izvršavanju Državnog proračuna Republike Hrvatske za 2016. godinu (Narodne novine, br. 26/2016).

20. Zakon o izvršavanju Državnog proračuna Republike Hrvatske za 2017. godinu (Narodne novine, br. 119/2016).

21. Zakon o naknadi za imovinu oduzetu za vrijeme jugoslavenske komunističke vladavine (Narodne novine, br. 92/1996, 39/1999, 42/1999, 92/1999, 43/2000, 131/2000, 27/2001, 34/2001, $65 / 2001,118 / 2001,80 / 2002$ i 81/2002).

22. Zakon o općem upravnom postupku (Narodne novine, br. 47/2009).

23. Zakon o parničnom postupku (Službeni list FNRJ, br. 4/1957 i 52/1961, Službeni list SFRJ, br. 12/1965, 1/1971, 23/1972 i 6/1974).

24. Zakon o parničnom postupku (Službeni list SFRJ, br. 4/1977, 36/1977, 36/1980, 6/1980, 69/1982, 43/1982, 58/1984, 74/1987, 57/1989, 20/1990, 27/1990, 35/1991 i Narodne novine, br. 53/1991, 91/1992, 112/1999, 129/2000, 88/2001, 117/2003, 88/2005, 2/2007, 96/2008, 84/2008, 123/2008, 57/2011, 25/2013 i 89/2014).

25. Zakon o porezu na dobit (Narodne novine, br. 177/2004, 90/2005, 57/2006, 146/2008, 80/2010, 22/2012, 148/2013, 143/2014, 50/2016 i 115/2016).

26. Zakon o republičkim sudskim taksama (Narodne novine, br. 19/1969, 10/1971, 14/1972, 26/1973 i 10/1977).

27. Zakon o sudskim pristojbama (Narodne novine, br. 20/1987, 55/1988,13/1989, 47/1989,11/1990,18/1990, 53/1991, 28/1992 i 66/1993).

28. Zakon o sudskim pristojbama (Narodne novine, br. 74/1995, 57/1996, 137/2002, 125/2011, 112/2012, 157/2013 i 110/2015).

29. Zakon o sustavu državne uprave (Narodne novine, br. 150/2011, 12/2013, 93/2016 i 104/2016).

30. Zakon o upravnim sporovima (Narodne novine, br. 20/2010, 143/2012, 152/2014, 94/2016 i 29/2017).

\section{POPIS SUDSKIH ODLUKA}

1. ESLJP: Airey protiv Irske (6289/73 od 9. listopada 1979.).

2. ESLJP: Amaç i Okkan protiv Turske (54179/00 i 54176/00 od 20. veljače 2008.).

3. ESLJP: Ashingdane protiv Velike Britanije (8225/78 od 28. svibnja 1985.).

4. ESLJP: Bakan protiv Turske (50939/99 od 12. rujna 2007.).

5. ESLJP: Brulla Gomez de la Torre protiv Španjolske (26737/95 od 19. prosinca 1997.).

6. ESLJP: C.M.V.M.C. O Limo protiv Španjolske (33732/05 od 24. studenog 2009.).

7. ESLJP: Eyüp Kaya protiv Turske (17582/04 od 23. prosinca 2008.).

8. ESLJP: FC Mretebi protiv Gruzije (38736/04 od 31. srpnja 2007.).

9. ESLJP: Golder protiv Ujedinjenog Kraljevstva (4451/70 od 21. veljače 1975.).

10. ESLJP: Iorga protiv Rumunjske (4227/02 od 25. siječnja 2007.). 
11. ESLJP: Jedamski i Jedamska protiv Poljske (73547/01 od 26. srpnja 2005.).

12. ESLJP: Kniat protiv Poljske (71731/01 od 26. srpnja 2005.).

13. ESLJP: Kreuz protiv Poljske (28249/95 od 19. lipnja 2001.).

14. ESLJP: Mehmet i Suna Yigit protiv Turske (52658/99 od 17. listopada 2007).

15. ESLJP: Polejowski protiv Poljske (38299/03 od 4. ožujka 2008.).

16. ESLJP: Podbielski i PPU Polpure protiv Poljske (39199/98 od 26. srpnja 2005.).

17. ESLJP: Teltronic-CATV protiv Poljske (48140/99 od 10. siječnja 2006.).

18. ESLJP: Tolstoy - Miloslavsky protiv Ujedinjenog Kraljevstva (18139/91 od 13. srpnja 1995.).

19. ESLJP: Tunç protiv Turske (20400/03 od 7. srpnja 2008.).

20. ESLJP: VP Diffusion Sarl protiv Francuske (14565/04 od 5. travnja 2004).

21. Europski sud pravde: DEB Deutsche Energiehandels- und Beratungsgesellschaft mbH protiv Njemačke (C-279/09, 22. prosinca 2010.).

22. Europski sud pravde: GREP GmbH protiv Slobodne Države Bavarske (C-156/12, 13. lipnja 2012.).

23. Ustavni sud RH: Odluka i Rješenje od 6. travnja 2011., posl. br. U-I-722/2009.

24. Ustavni sud RH: Rješenje od 23. studenog 2005., posl. br. U-I949/1995.

25. Ustavni sud RH: Rješenje od 11. srpnja 2007., posl. br. 11. U-I-500/2004.

26. Ustavni sud RH: Rješenje od 3. ožujka 2010., posl. br. U-III-1811/2007.

27. Ustavni sud RH: Rješenje od 28. listopada 2010., posl. br. U-III-2347/2010.

28. Ustavni sud RH: Rješenje od 20. rujna 2012., posl. br. U-I-4144/2012.

29. Visoki trgovački sud RH: Odluka od 3. prosinca 1996., posl. br. Pž- 2959/96.

30. Županijski sud u Varaždinu: Rješenje od 22. rujna 2014., posl. br. Gž-4590/14.

31. Županijski sud u Varaždinu: Rješenje od 1. travnja 2015., posl. br. Gž-4733/14.

32. Županijski sud u Varaždinu: Rješenje od 25. rujna 2015., posl. br. Gž-2254/14.

33. Županijski sud u Zagreb: Rješenje od 28. siječnja 2014., posl. br. Gž-7559/13.

\section{MREŽNI I OSTALI IZVORI}

1. European judicial systems: Efficiency and quality of justice. CEPEJ Studies, No. 23, Ed. 2016 (2014 data),http://www.coe.int/t/dghl/cooperation/cepej/evaluation/2016/publication/CEPEJ\%20 Study\%2023\%20report\%20EN\%20web.pdf (21. ožujka 2017.).

2. Izvješća Ministarstva pravosuđa o ostvarivanju prava na besplatnu pravnu pomoć i utrošku sredstava, https://pravosudje.gov.hr/pristup-informacijama-6341strategije-planovi-i-izvjesca/izvjesce -o-ostvarivanju -prava-na-besplatnu-pravnu-pomoc-i-utrosku-sredstava/6723 (15. travnja 2017.).

3. Konačni prijedlog Zakona o besplatnoj pravnoj pomoći, Vlada Republike Hrvatske, 2008.

4. Konačni prijedlog Zakona o izmjenama i dopunama Zakona o besplatnoj pravnoj pomoći, Vlada Republike Hrvatske, 2011.

5. Korisnici i usluge socijalne skrbi u 2011., Državni zavod za statistiku, Priopćenje broj 8.4.1., Zagreb, 9. srpnja 2012., www.dzs.hr/Hrv-Eng/publication/2012/08-04-01-01-2012.htm (28. travnja 2017.).

6. Mišljenje nezavisnog odvjetnika Mengozzija od 2. rujna 2010. u predmetu DEB Deutsche Energiehandels- und Beratungsgesellschaft mbH protiv Njemačke (C-279/09). 
7. M. R., Prijete sankcije: Hrvatska kasni s implementacijom europskih direktiva o javnoj nabavi i koncesijama, Portal index.hr: 24. svibnja 2016., www.index.hr/vijesti/clanak/prijete-sankcije-hrvatska-kasni-s-implementacijom-europskih-direktiva-o-javnoj-nabavi-i-koncesijama/895218.aspx (24. ožujka 2017.).

8. Odluka Ekonomskog i socijalnog vijeća (Službeni glasnik C 221, 17. rujna 2002., str. 64.-67., celex 52002AE0687).

9. Prijedlog Direktive o unapređenju pristupa pravosuđu u prekograničnim sporovima utvrđivanjem minimalnih zajedničkih pravila o pravnoj pomoći u takvim sporovima, $\operatorname{COM(2002)} 13$ final 2002/0020 (CNS), celex 52002AE0687.

10. Uputa Ministarstva pravosuđa uredima državne uprave od 22. travnja 2010. (Klasa: 007-01/0901/223, Ur. broj: 514-05-03-02/1-10-51). 


\section{COURT FEES WAIVER AS A PRECONDITION OF ACCESS TO JUSTICE}

\section{Summary}

Croatian court fees waiver system has changed fundamentally in recent years. Unlike prior legislative solution, administrative bodies now grant waivers instead of courts and the criteria for waiver are expressly and strictly prescribed by the law. Introduction of specialized administrative body which decides in accordance with predetermined rules was expected to increase the number of waivers and to create wider access to the system in general. Although the reports of Ministry of Justice show the constant increase of cases in which court fee was waived, those numbers cannot alone confirm if the systems functions properly and to what extent. This paper thus compares Croatian legislative solutions and their application with the case of law of European Court of Human Rights, while the number of waivers is compared with the number of enforcement proceedings initiated due to the non-payment of court fees. In accordance with such comparative analysis and empirical data, this paper makes conclusions on (non)functioning of the system and makes proposals for the necessary amendments.

Keywords: $\quad$ court fees, court fees waiver, access to justice

\section{(c) (1) (s)}

This work is licensed under a Creative Commons

Attribution-NonCommercial 4.0 International License.

* Juraj Brozović, LLM, Assistant, Chair of Civil Procedural Law, Faculty of Law, University of Zagreb. Trg maršala Tita 14, 10000 Zagreb, Republic of Croatia. E-mail address: juraj.brozovic@pravo.hr. ORCID: http://orcid.org/0000-0003-2362-4580. 